\title{
The Potential Impact of Externalities Considerations on the Market for Biomass Power Technologies
}

Blair G. Swezey, Kevin L. Porter, and J.Sherman Feher

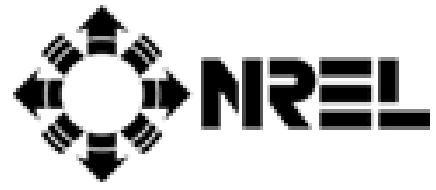

National Renewable Energy Laboratory 1617 Cole Boulevard Golden, Colorado 80401-3393

A national laboratory of the U.S. Department of Energy Managed by Midwest Research Institute for the U.S. Department of Energy under contract No. DE-AC36-83CH10093

February 1994 


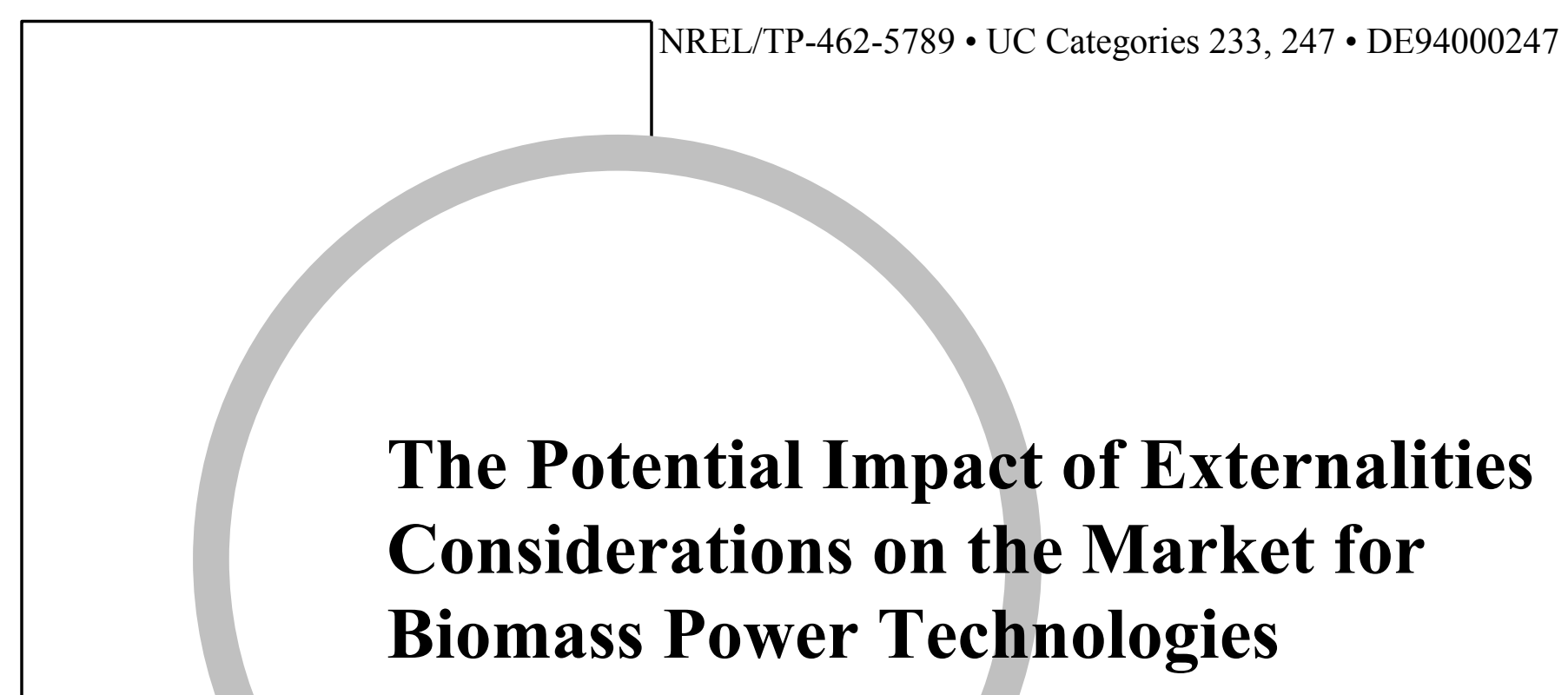

Blair G. Swezey, Kevin L. Porter, and J.Sherman Feher

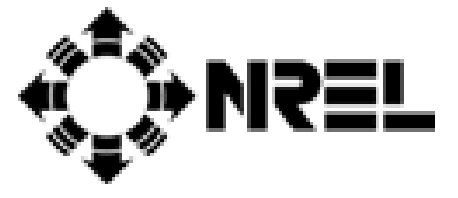

National Renewable Energy Laboratory 1617 Cole Boulevard

Golden, Colorado 80401-3393

A national laboratory of the U.S. Department of Energy Managed by Midwest Research Institute for the U.S. Department of Energy under contract No. DE-AC36-83CH10093

Prepared under Task Nos. BF165155 and BF261011

February 1994 


\section{NOTICE}

This report was prepared as an account of work sponsored by an agency of the United States government. Neither the United States government nor any agency thereof, nor any of their employees, makes any warranty, express or implied, or assumes any legal liability or responsibility for the accuracy, completeness, or usefulness of any information, apparatus, product, or process disclosed, or represents that its use would not infringe privately owned rights. Reference herein to any specific commercial product, process, or service by trade name, trademark, manufacturer, or otherwise does not necessarily constitute or imply its endorsement, recommendation, or favoring by the United States government or any agency thereof. The views and opinions of authors expressed herein do not necessarily state or reflect those of the United States government or any agency thereof. 


\section{Preface}

One intended result of federal investments in renewable energy research and development (R\&D) programs is the adoption and use of renewable energy technologies in the energy marketplace. Insights into the nature of energy markets can help to assure that the technologies being developed are compatible with these markets. This document reports on the findings of a study to assess the potential impact of externalities considerations on the market prospects for different biomass resources and technologies, particularly wood and agricultural wastes, waste-to-energy, and landfill gas.

States are increasingly contemplating inclusion of the non-market costs and benefits of generation options in electricity resource planning and procurement decisions. These market externalities represent impacts that are not wholly reflected in the market price of electricity from different generation resources. These impacts, which can be either positive or negative, may encompass environmental, economic, and other social factors. The explicit consideration of externalities could measurably impact the competitive standing of various energy resources and technologies in future utility resource acquisitions.

This report begins with an overview of the current status of biomass-based power development in the United States and the prospects for future development in today's more competitive market environment, followed by a general description of biomass power technologies and their externalities. We then review the degree to which externalities are being considered in state resource planning decisions, including the extent to which biomass technologies have been or could be impacted by these considerations. Finally, a number of electric utility and biomass industry representatives were contacted to assess industry perceptions of the externalities related to biomass energy resources and technologies and the degree to which these externalities may help or hinder biomass development.

The Analytic Studies Division (ASD) of the National Renewable Energy Laboratory (NREL) supports the long-range planning of the overall federal renewable energy R\&D program, both at NREL and the U.S. Department of Energy (DOE), by conducting analyses on aspects of energy market competition that are relevant to the present and future deployment of renewable energy technologies. The ASD reports on these efforts to DOE and NREL managers to enhance their awareness of competitive and institutional factors that may impact on the successful deployment of renewable energy technologies in the marketplace.

This study was conducted for the DOE Office of National Programs in the Office of Technical and Financial Assistance in the Office of Energy Efficiency and Renewable Energy. The authors wish to thank Carl Wallace of NREL for his general support of this work. The authors also wish to thank the many biomass and utility industry representatives who provided the industry perspectives that are summarized in Chapter 4.

The text of the report was improved greatly from information and comments received from many people including Tony Alvarez, Jim Easterly, and Janine Finnell, Meridian Corp.; Phillip C. Badger, Tennessee Valley Authority; Steve Bernow, Tellus Institute; Shahid Chandhry, California 
Energy Commission; Julie Hashem, Barakat \& Chamberlin, Inc.; Paul Hibbard, Massachusetts Department of Public Utilities; David Iliff, Wisconsin Public Service Commission; Jonathan V. L. Kiser, Integrated Waste Services Association; Phil Lusk, Consultant; Russ O'Connell, Coalition of Northeastern Governors; Ralph Overend, National Renewable Energy Laboratory; Nancy Pitblado, Connecticut Department of Policy and Management; Dave Swanson, Western Area Power Administration; Jane Turnbull, Electric Power Research Institute; and Carl Vansant, Solid Waste \& Power magazine. However, the interpretation of this information, as presented in this report, remains the sole responsibility of the authors.

Approved for the

NATIONAL RENEWABLE ENERGY LABORATORY

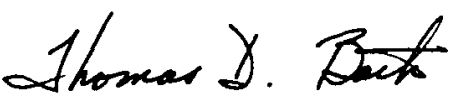

Thomas D. Bath, Director Analytic Studies Division

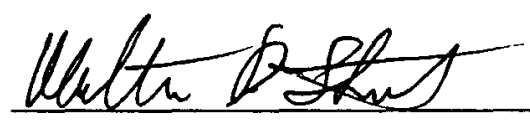

Walter D. Short, Manager Market Analysis Branch 


\section{Executive Summary}

Of all the renewable energy sources used for power generation, biomass energy has experienced the greatest growth over the last decade. Spurred by requirements established in the Public Utility Regulatory Policies Act of 1978 (PURPA), as well as various tax incentives, biomassbased power generation now provides more than 50 billion $\mathrm{kWh}$ of electric energy from 10,000 MW of installed capacity. The overwhelming majority of this capacity, primarily wood-based, has been developed by the nonutility sector. However, the biomass industry is currently facing more difficult market conditions due to a reduction in federal incentives and changes in the generation market, such as lower utility avoided costs, slower demand growth, and greater competition among fuel sources.

States are increasingly contemplating the inclusion of market externalities costs and benefits associated with different generation options in electricity resource planning and procurement decisions. Market externalities, as they relate to generation resources and technologies, represent impacts that are not wholly reflected in the market price of electricity derived from these sources. These impacts, which can be either positive or negative, can encompass environmental, economic, and other social factors, but state considerations have focused predominately on environmental externalities costs, especially air emissions. The explicit quantification of externalities could measurably affect the competitive standing of various energy resources and technologies in future utility resource acquisitions.

The objective of this study was to assess the current status of externalities considerations in state and utility electricity resource planning processes and to determine how externalities considerations might help or hinder future development of biomass power plants. In the following chapters, we provide an overview of biomass resources and technologies, including their market status and environmental impacts; review the current treatment of externalities in the states; and document the perspectives of key utility, regulatory, and industry representatives on externalities considerations. However, this report is not intended to be a definitive study of environmental externalities. Nor do we intend to suggest the extent to which externalities should be considered in state or utility resource planning deliberations nor to suggest how externalities could be used to promote greater adoption of biomass power technologies.

Although states are increasingly considering environmental and other socioeconomic externalities as a component of electricity resource planning and acquisition processes, both the methods utilized and the scope of these considerations differ widely. Through 1992, 29 states had existing requirements for electric utilities to consider externalities in resource planning and/or acquisition, and an additional 7 states were considering adopting externalities requirements. Air emissions have received the most attention in externalities deliberations. While some states have attempted to consider economic and fuel risk externalities as well, these considerations are not well developed at present.

The majority of states considering externalities do so qualitatively. This type of consideration can range from a fairly superficial treatment in planning to explicit weighting in resource procurement decisions. Only five states (California, Massachusetts, Nevada, New York, and 
Wisconsin) have established monetized values for environmental externalities based on residual air emissions. Table ES-1 presents NREL-calculated externalities costs by generation technology based on the emissions values adopted in each of these five states.

\begin{tabular}{||lccccc||}
\hline \multicolumn{5}{|c|}{$\begin{array}{c}\text { Table ES-1. Representative Environmental Adders for States with Monetized Externalities } \\
\text { (cents/kWh, \$1992) }\end{array}$} & \multicolumn{3}{||}{} \\
\hline \hline Fuel - Technology & California & Massachusetts & Nevada & New York & Wisconsin \\
\hline \hline Coal - Pulverized (NSPS) & 2.2 & 4.0 & 4.0 & 0.6 & 1.7 \\
Coal - AFB & 1.7 & 3.7 & 3.6 & 0.3 & 1.8 \\
Coal - IGCC & 1.0 & 2.5 & 2.5 & 0.2 & 1.4 \\
Natural Gas - Combined Cycle & 0.7 & 1.5 & 1.4 & 0.1 & 0.7 \\
Natural Gas - Combustion Turbine & 1.1 & 2.4 & 2.4 & 0.2 & 1.2 \\
Wood - Steam & 1.9 & $5.2 / 0.9$ & $4.8 / 0.7$ & $0.3 / 0.1$ & $2.7 / 0.1$ \\
Biomass - Advanced Gasification & 1.2 & $3.0 / 0.3$ & $3.0 / 0.3$ & $0.2 / 0.1$ & $1.7 / 0.1$ \\
Municipal Solid Waste & 1.8 & 4.9 & 4.7 & 0.3 & 2.2 \\
Landfill Methane & 1.7 & $3.2 /-2.8$ & $3.0 /-2.9$ & 0.4 & $1.0 /-2.7$ \\
Geothermal - Flashed Steam & $<0.1$ & NA & $<0.1$ & NA & NA \\
Solar - Trough with Gas Backup & 0.7 & NA & 1.8 & NA & NA \\
\hline
\end{tabular}

$\mathrm{NA}=$ not applicable

Note: For wood and advanced biomass, the first value represents total externalities without $\mathrm{CO}_{2}$ offsets credit and the second value with $\mathrm{CO}_{2}$ offsets for those state commissions that have explicitly considered offsets or in which commission staff have expressed support for $\mathrm{CO}_{2}$ offsets. For landfill methane, the second value represents a credit for methane emissions reductions for those states that have monetized methane emissions; however, none of these states currently allow negative values to be applied. See Chapter 3 for other table assumptions.

Among fossil fuel combustion technologies, natural-gas-based plants have the lowest total externalities costs, while coal-fired plants have the highest. The magnitude of the adders for biomass-based technologies depends greatly on whether biomass projects are judged to be neutral with regard to greenhouse gas emissions because of carbon dioxide $\left(\mathrm{CO}_{2}\right)$ sequestration.

Some of these states are now considering the use of carbon-fixing offsets for wood and agricultural waste if it can be shown that the fuel supply is sustainably managed. In Massachusetts, the only state that has specifically approved this approach, $\mathrm{CO}_{2}$ emissions offsets would lower the total externalities adder for a representative wood project from $5.2 \varnothing / \mathrm{kWh}$ to $0.9 \notin / \mathrm{kWh}$, which is less than the adder for a natural gas combined cycle plant, generally regarded as the "cleanest" fossil-fuel-based generation option.

Another emerging trend in these states is to allow offsets to some or all externalities adders. To the extent that offsets can be obtained at relatively low cost, any advantages that biomass and other renewables would receive under externalities considerations would be eroded.

It is still too early to ascertain to what extent externalities considerations will impact resource planning and acquisition decisions. There is currently little, if any, evidence indicating that the 
qualitative consideration of externalities is having an impact on resource choices. The impact of externalities monetization is also unclear, partly because in some states, e.g., California, resource choices have not yet been finalized utilizing these values, and partly because the sluggish economy has delayed the need for new resources in Massachusetts and New York. The little experience that is available to date suggests that externalities considerations favor the selection of natural gas projects over coal, with renewables receiving little or no advantage vis-ávis natural gas.

Externalities rulemakings have generated significant controversy, and, in some cases, lawsuits or legislative efforts have been pursued to overturn these actions. These controversies have generally made it difficult to implement externalities considerations in any meaningful way. For this reason, several states and utilities are pursuing other avenues to promote "cleaner" energy sources. These activities include the use of "green RFPs" (request for proposals), capacity setasides, and regulatory incentives or mandates for the development of renewable energy sources.

Discussions with representatives of the biomass industry, the electric utility industry, and state regulatory agencies confirmed many of the foregoing observations regarding the current utility market environment for biomass generation and biomass externalities. It was noted that the public perception of biomass development varies widely. The environmental characteristics of biomass projects can be viewed as both potential positives and negatives but, generally, biomass externalities are considered to be more favorable than those associated with coal but less favorable than those of natural gas or other renewables-based resource options. Several respondents also noted, as we have here, that the treatment of greenhouse gas offsets will be an important factor in the relative externalities valuation of biomass projects.

Finally, it was noted that only a handful of electric utilities have direct experience with biomass power development because the majority of this development has been carried out by nonutility developers. State utility regulators also appear to have paid less attention to the relative benefits of biomass development compared to traditional fossil-fuel-based generation. Most state regulators focus on traditional project economics.

\section{Recommendations}

Based on our analysis of externalities considerations in the states, we make the following recommendations to the biomass industry:

- Because the valuation of $\mathrm{CO}_{2}$ emissions can represent a large fraction of the total emissions-related externalities adder, the wood and agricultural waste industries should actively work toward achieving recognition among all states and utilities that these resources are greenhouse gas neutral because of carbon sequestration during growth. To date, only one state has formally adopted this policy even though it has been considered in several other states. Greenhouse gas neutrality considerations should also be extended to landfill methane and municipal solid waste resources because of their potential to reduce formation or seepage of methane, a potent greenhouse gas, in landfills. 
- Given that, to date, the valuation and application of environmental externalities have proved difficult in many states, the biomass industry should also emphasize nonenvironmental benefits, such as economic development and job creation, that accompany biomass development. Although some states have rejected attempts at quantifying economic externalities, this approach may succeed if it can be shown that the economic benefits represent real gains over other options, such as the use of indigenous rather that imported (out-of-state) fuels. This would require broadening the externalities debate in many states.

- In addition to explicit externalities valuation, the biomass industry should pursue and support efforts to establish renewable energy set-asides or green RFPs. Because biomass technologies are well established in the marketplace, biomass projects are well positioned to compete against other renewables in these types of solicitations. 


\section{Table of Contents}

1. Current Assessment of Biomass Power Generation $\ldots \ldots \ldots \ldots \ldots \ldots \ldots$

2. Biomass Combustion and Externalities $\ldots \ldots \ldots \ldots \ldots$

3. Trends in State Externalities Consideration $\ldots \ldots \ldots \ldots \ldots \ldots$

4. Perceptions of Biomass Power Technologies $\ldots \ldots \ldots \ldots \ldots \ldots$

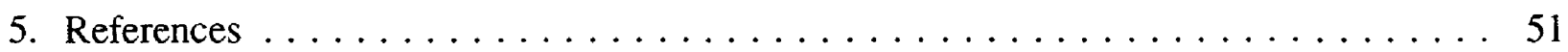

\section{List of Figures}

Figure 1-1. Nonutility-developed, wood-fired capacity by region $-1992 \ldots \ldots$

Figure 1-2. Nonutility-developed, agricultural-waste-fired capacity by region $-1992 \ldots \ldots 3$

Figure $1-3$. Location of waste-to-energy plants by state $\ldots \ldots \ldots \ldots \ldots$

Figure 1-4. Location of landfill methane power plants by state $\ldots \ldots \ldots \ldots$

\section{List of Tables}

Table 1-1. Biomass Capacity and Generation (1992) . . . . . . . . . . . . 2

Table 2-1. Chemical Analysis Comparison of Specific Biomass and Coal Fuels . . . . . 14

Table 3-1. Values for Environmental Factors Applied to a Coal Plant in New York . . . 31

Table 3-2. Comparative Externality Values Adopted for $\mathrm{CO}_{2}$ Emissions . . . . . . . 32

Table 3-3. Representative Environmental Adders for States with Monetized Externalities ........................ 33

Table 3-A. Status of Externalities Consideration in the States $\ldots \ldots \ldots \ldots$

Table 3-B. Representative Emissions Factors and Heat Rates for New Plants Utilized in Table $3-3 \ldots \ldots \ldots \ldots \ldots \ldots \ldots \ldots \ldots \ldots$ 


\section{Current Assessment of Biomass Power Generation}

\section{Introduction}

Of all the renewable energy sources, biomass energy has seen the greatest growth over the last decade. Spurred by the Public Utility Regulatory Policies Act of 1978 (PURPA) and tax incentives for nonutility generators (NUGs), biomass-based power generation now provides more than 50 billion $\mathrm{kWh}$ of electric energy from 10,000 MW of installed capacity. The overwhelming majority of this capacity, primarily wood-based, has been developed by the nonutility sector (Table 1-1).

This section reviews the recent development history and the prospects for future development of the major biomass resource types: wood and agricultural (ag) waste, municipal solid waste (waste-to-energy), and landfill gas.

\section{Wood and Agricultural Waste}

Wood is the leading biomass energy resource primarily due to its use as a boiler fuel in the pulp and paper and forest products industries. The lumber industry satisfies close to $75 \%$ of its energy needs through direct wood combustion and the pulp and paper industry has achieved a 55\% aggregate fuel contribution from wood (Williams and Porter 1989). Electricity is also generated from wood, using cogeneration technology. It is estimated that more than $6000 \mathrm{MW}$ of nonutility-owned, wood-fired generating capacity was in place at the end of 1992, up from $200 \mathrm{MW}$ of grid-connected capacity in $1980 .^{1}$ Agricultural waste plants, utilizing such diverse feedstocks as bagasse, rice hulls, rice straw, nut shells, crop residues, and prunings from orchards and vineyards, account for more than $500 \mathrm{MW}$.

Electric utilities were early leaders in dedicated power generation from wood (Williams and Porter 1989). In 1983, Washington Water Power Company constructed the nation's first utilitygrade wood plant, a 46-MW plant in Kettle Falls, Washington. This plant was followed in 1984 by a 50-MW project in Burlington, Vermont, operated by the Burlington Electric Department. Prior to these two plants, Northern States Power, in 1979 and 1980, had converted two fossil plants in Wisconsin to burn wood and refuse-derived fuels (Musso 1991). However, direct utility development of wood-fired power plants has not progressed beyond a few isolated projects. Although most utilities have not been directly involved in wood and ag waste project development, utility subsidiaries have participated in the financing and development of many projects.

Nonutility producers have been responsible for the bulk of activity in biomass power plant development. The driving forces behind this development were PURPA and favorable federal tax treatment, such as the business energy tax credit for biomass projects that was in effect between 1980 and 1988 and rapid depreciation schedules (Williams and Porter 1989). Along with

\footnotetext{
${ }^{\text {I}}$ The 1991 estimate is from (EEI 1993) and the 1980 estimate is from (Rinebolt 1990).
} 


\begin{tabular}{|c|c|c|}
\hline Energy Source & $\begin{array}{c}\text { Capacity } \\
\text { (MW) }\end{array}$ & $\begin{array}{c}\text { Generation } \\
\text { (billion } k W h \text { ) }\end{array}$ \\
\hline Wood/Wood Waste & $6,381.8$ & 32.2 \\
\hline Agricultural Waste & 568.2 & 3.1 \\
\hline Municipal Solid Waste & $2,228.9$ & 12.0 \\
\hline Landfill Gas & 418.3 & 2.3 \\
\hline Utility Biomass & 464.0 & 2.1 \\
\hline Total Biomass & $10,061.2$ & 51.7 \\
\hline
\end{tabular}

Sources: (EEI 1993) and (USDOE 1993b)

other nonutility developers, many wood and ag waste developers took advantage of favorably priced utility contracts that were made available in California, Maine, and other states to both implement PURPA and displace oil-fired generation. The Pacific Gas and Electric Company (PG\&E) has reported that more than $900 \mathrm{MW}$ of biomass capacity (more than $700 \mathrm{MW}$ based on wood and ag waste) were developed within its service territory during the 1980s (Tumbull et al. 1991).

Development of wood and ag waste plants has been most prevalent in those regions with established biomass production industries (Figures 1-1 and 1-2). PURPA has encouraged many forest products companies to sell excess power to utilities in addition to meeting their own energy needs. Some states such as Alabama, California, Georgia, and North Carolina have promoted the use of wood waste for energy production. For example, using oil overcharge funds, Alabama's state energy office subsidizes the interest on bank loans to small secondary forestproduct industries that purchase wood boilers. And California has conducted a wood waste demonstration program (Rader et al. 1990).

In addition, the development of wood and ag waste power plants has often helped address local environmental problems. For example, the Kettle Falls plant has helped reduce localized air pollution resulting from the burning of waste wood in sawmill wigwam burners without emissions controls (NREL 1993). Ag waste plants built in the Central Valley in California have helped cut down on the traditional open field burning of agricultural residues (Turnbull et al. 1991).

Fuel preparation and transportation are often the major expense items for wood and ag waste plant operation. To minimize fuel transportation expenses, plants must generally be sited within a 50-mile radius of the fuel source. This same criterion also tends to limit plant size to $50 \mathrm{MW}$ or less (Williams and Porter 1989). Because fuel handling requirements can be extensive, biomass-fueled plants are typically more labor intensive than fossil-fueled plants (Turnbull et al. 1991). 


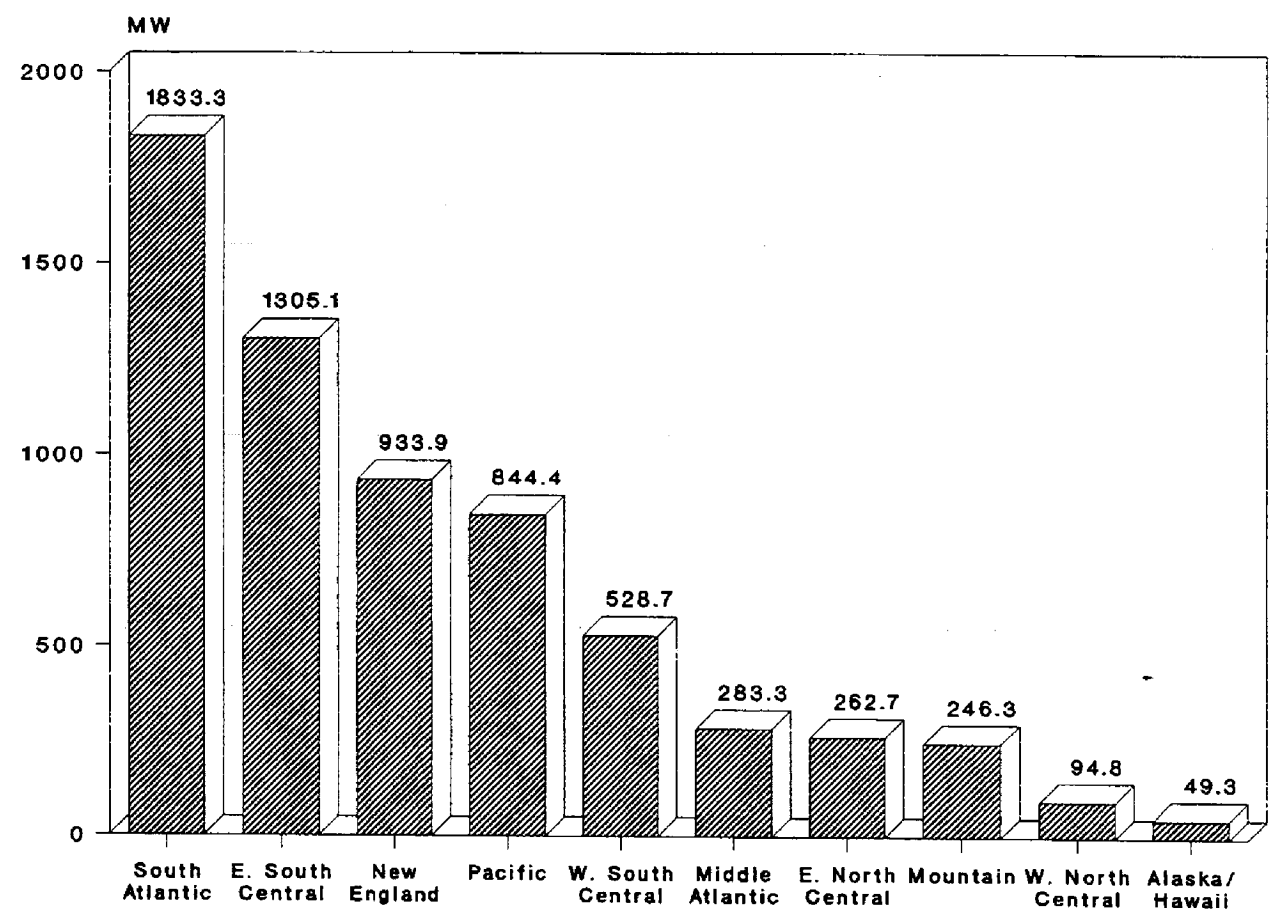

Figure 1-1. Nonutility-developed, wood-fired capacity by region - 1992

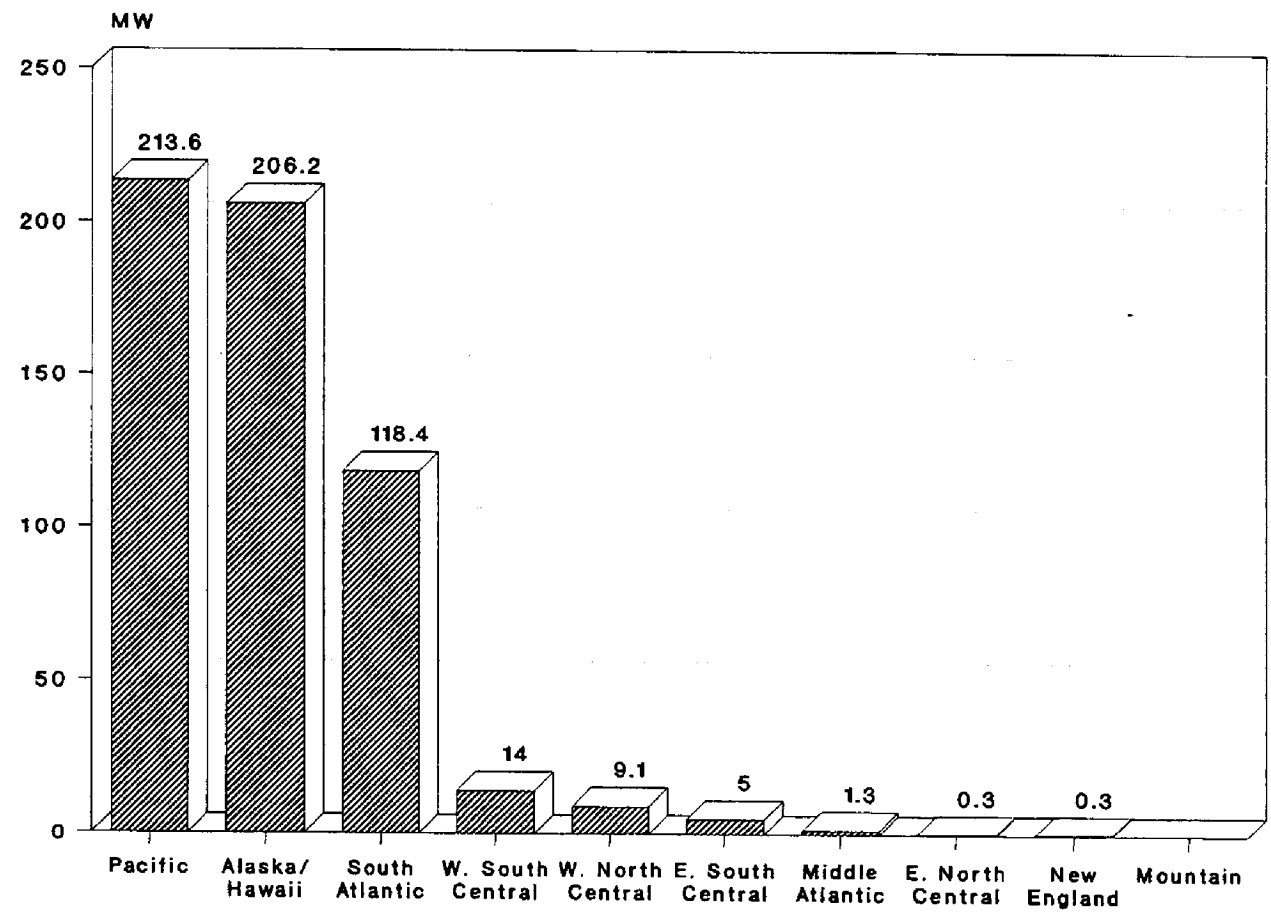

Figure 1-2. Nonutility-developed, agricultural-waste-fired capacity by region - 1992 Source for both figures: (EEI 1993) 
Urban wood wastes are emerging as an important fuel source. Municipal landfills and transfer stations are the primary sources of urban wood waste along with building demolition sites. Urban waste wood has an important cost advantage because suppliers may often pay a tipping fee for disposal. However, this waste wood can contain as much as $20 \%$ to $30 \%$ non-wood materials, such as paints, metals, preservatives, binders, and resins. State or local air quality regulations may require these materials to be removed before the waste wood is combusted (Peterson 1991). In California, plant operating permits clearly specify the types of fuels that can be burned. Operators of current facilities may be hesitant to apply for special permits for fear of reopening the original plant operating permits to public scrutiny (Morris 1991).

The expiration of the federal renewable energy tax credits, plummeting avoided cost rates, and intensifying competition from fossil fuels have posed obstacles for the continued development of wood-fired plants. Avoided costs have fallen from as high as $10 \mathrm{k} / \mathrm{kWh}$ in the early $1980 \mathrm{~s}$ to between $3 \not c$ and $5 \not / \mathrm{kWh}$ today (Swezey 1993). As a result of these conditions, wood-fired capacity additions fell from $614 \mathrm{MW}$ in 1989 to between 250 and $300 \mathrm{MW}$ in 1990 (USDOE 1993a).

In addition, regional or local slowdowns in economic activity have caused perturbations in agricultural and wood waste supplies and prices. The closing of a Weyerhauser plant in Wisconsin resulted in Northern States Power losing 15\% of the wood supply for the French Island wood-fired power plant (Musso 1991). Conversely, the closing of a Wisconsin particle board plant created a financial loss for two sawmill operations that provided biomass boiler fuel to the plant (Sweet 1991; Talbot 1991).

Wood and agricultural waste fuel shortages and disruptions have been especially severe in northern California. Waste fuel prices soared in 1989 and 1990 when more than $200 \mathrm{MW}$ of wood and agricultural waste plants came on-line in the Pacific Gas and Electric Company (PG\&E) service territory, straining local fuel supplies and prompting some developers to truck in waste fuel from hundreds of miles away to assure power generation during PG\&E's lucrative peak hours (Turnbull, et al. 1991). Fuel prices climbed again in 1991 when the state recession caused a downturn in logging operations, reducing fuel supplies and raising prices. These fuel price movements have threatened the financial viability of several biomass plants in California, especially those plants without a captive fuel source (EUW 1992). Furthermore, federal logging restrictions in the Northwest imposed to protect spotted owl habitat may further reduce future timber harvests and strain fuel supplies. As a result of the waste fuel market turmoil, a waste fuel brokering industry is developing in California and the Pacific Northwest to broker waste from sawmills, logging operations, and municipal waste landfills. These brokers may play an important future role in providing more stability in the waste fuel market (Turnbull, et al. 1991).

Wood waste plants have been the target of some public opposition because of concerns that the demand for wood resources may eventually lead to clear-cutting. Communities have also objected to power plants because of noise and traffic disruption resulting from the trucking of wood supplies. Other environmental impacts include dust, noise, and smoke from plant operations and odor from fermenting fuel piles (Williams and Porter 1989). Although wood waste plants emit considerably less sulfur and nitrous oxides $\left(\mathrm{SO}_{\mathrm{x}}\right.$ and $\mathrm{NO}_{\mathrm{x}}$, respectively) than fossil fuel plants, emissions of particulates, trace volatile organic compounds (VOCs), and carbon 
monoxide are higher (CTOPM 1990). A number of proposed plants have been abandoned because of public opposition.

However, wood and ag waste plants also offer certain environmental advantages, in addition to lower $\mathrm{SO}_{\mathrm{x}}$ and $\mathrm{NO}_{\mathrm{x}}$ emissions. Plants can provide a market for biomass wastes, encourage better forest management practices through thinning of dense or older stands, and avoid open burning of wastes (CTOPM 1990). For example, California allows air emissions offsets to facilities burning agricultural and forestry wastes that otherwise would have been burned in open fields (Morris 1991). And although the combustion of biomass wastes releases carbon dioxide $\left(\mathrm{CO}_{2}\right)$, a greenhouse gas, wood and ag waste plants release no net $\mathrm{CO}_{2}$ emissions (in a sustainably managed system) because the plants and trees absorb $\mathrm{CO}_{2}$ during growth. Wood and ag waste combustion might also displace methane emissions that would have resulted from the decomposition of these materials (Chupka et al. 1992).

Despite many obstacles, wood and agricultural waste projects continue to move forward, although at a slower pace than in the past. One possible reason is that these projects have attractive economics due to their utilization of traditional combustion technologies and low-cost waste feedstocks. Compared to other renewable technologies, biomass projects have fared relatively well in utility competitive bidding solicitations. Through 1992, more than $640 \mathrm{MW}$ of wood projects had been selected through bidding, more than any other renewable energy resource, although these figures are dwarfed by natural gas and coal projects (Swezey 1993).

Further growth could be achieved through repowering existing plants with higher efficiency conversion technologies, utilizing larger plant sizes and co-firing with other fuels (Turnbull et al. 1991). Wood may provide an attractive co-firing option (with coal) for utilities facing requirements for significant reductions of sulfur dioxide $\left(\mathrm{SO}_{2}\right)$ emissions under the 1990 Clean Air Act Amendments (CAAA). The Tennessee Valley Authority (TVA) is conducting case studies at three of its coal plants to determine the feasibility of co-firing wood-derived fuel and coal. Besides the value of reducing $\mathrm{SO}_{2}$ and $\mathrm{NO}_{\mathrm{x}}$ emissions, TVA is investigating wood co-firing as a $\mathrm{CO}_{2}$ mitigation option in anticipation of future legislative or regulatory requirements (Gold and Tillman 1993). TVA estimates that enough unused milling and logging residues exist in its service territory to supply fuel for 200 to $400 \mathrm{MW}$ of wood co-firing capacity at a retrofit cost of about $\$ 50 / \mathrm{kW}$ (or about $\$ 410 / \mathrm{kW}$ for whole tree combustion) (McGowin and Gold 1992; Gold and Tillman 1993).

Additional market growth could be realized by the use of fast-growing, biomass-based energy crops, such as hybrid poplar or switchgrass. Energy crops could be grown on crop set-aside lands as a means of protecting against soil erosion and crop overproduction, as well as being an economic stimulus to rural areas. The Energy Policy Act of 1992 (EPACT) includes a 10-year, $1.5 \notin / \mathrm{kWh}$ production tax incentive for new biomass power systems that utilize such "closed loop" biomass resources. However, several programs, administered by the U.S. Department of Agriculture (USDA), create disincentives for the production of biomass-based energy crops. For example, federal crop support payment programs discourage planting of new types of crops. And acreage reduction programs pay farmers not to plant a portion of their farm land if it is determined that there will not be a market for the commodity crop that would have been planted (USDOE 1993a). Both of these programs come up for Congressional reauthorization in 1995. 
Additional market opportunities might be realized by the introduction of biomass integrated gasifier turbines. Gasifier systems could achieve higher conversion efficiencies of $40 \%$ or more, compared to $25 \%$ for conventional wood systems, and have projected capital costs of $\$ 1,000$ to $\$ 1,250 / \mathrm{kW}$, lower than the $\$ 1,500$ to $\$ 2,500 / \mathrm{kW}$ for new steam-fired, wood plants. States with large forest resources and little biomass electric capacity may offer market growth opportunities (Anderson 1991). Still, improved market conditions, such as higher avoided cost rates, may be needed if the wood and agricultural waste industries are to match the growth of the 1980s.

\section{Waste-to-Energy}

Waste-to-energy (WTE) represented one of the fastest growing renewable energy industries of the 1980s. As of early 1993, there were 171 WTE steam and electric plants operating or under construction in the United States, with a net electric generating capacity of $2962 \mathrm{MW}$, up from 78 plants and $538 \mathrm{MW}$ in 1986. Another 21 plants, totaling $797 \mathrm{MW}$, are in either advanced development or under construction (Berenyi and Gould 1993).

Several factors contributed to the industry's growth over this period. Landfills have become increasingly difficult to site because of public opposition, lack of sites, and increasing costs to comply with environmental standards. Furthermore, many existing landfills were nearing their rated capacity. In 1987, it was estimated that two-thirds of all municipalities would exhaust their existing landfill capacity by the turn of the century (Williams and Porter 1989). WTE plants quickly became the waste disposal option of choice.

Like many other renewables, WTE plants were also eligible for a number of federal financial incentives such as the 10\% investment tax credit (through 1985) and rapid depreciation schedules. The enactment of PURPA in 1978 gave developers a market for electricity generated from waste combustion. Until PURPA, process steam represented the sole energy-related market product from waste combustion. Today, revenues from electricity sales can offset from $35 \%$ to $70 \%$ of the annual cost of a WTE plant (Williams 1991).

Waste-to-energy plants are operating or are planned in 37 states (Figure 1-3). The Northeast has the greatest concentration of plants, followed by the South, the North Central region, and the West. High tipping fees and a shortage of landfill capacity have led to the greater development in the Northeast. Through the 1980s, the WTE industry expanded at a rapid rate; 65 plants came on line between 1988 and 1990 alone (Berenyi and Gould 1993). Despite this activity, many of the factors that drove WTE development in the past have changed, and growth in the WTE industry has slowed dramatically (Kiser 1992b). For example, the number of projects in conceptual planning has dropped from 139 in 1988 to 27 in 1992, and 77 planned projects have been canceled since 1991 (Berenyi and Gould 1993).

The Tax Reform Act of 1986 eliminated the federal investment tax credit, accelerated depreciation, and interest deduction provisions for WTE projects and also scaled back the ability of states to finance projects with tax-exempt municipal bonds. As a result, there were two surges in WTE development, one at the end of 1985 to take advantage of the expiring federal tax incentives and another through the end of 1987 to utilize the higher state cap on private activity, tax-exempt municipal bonds (Williams 1991). 


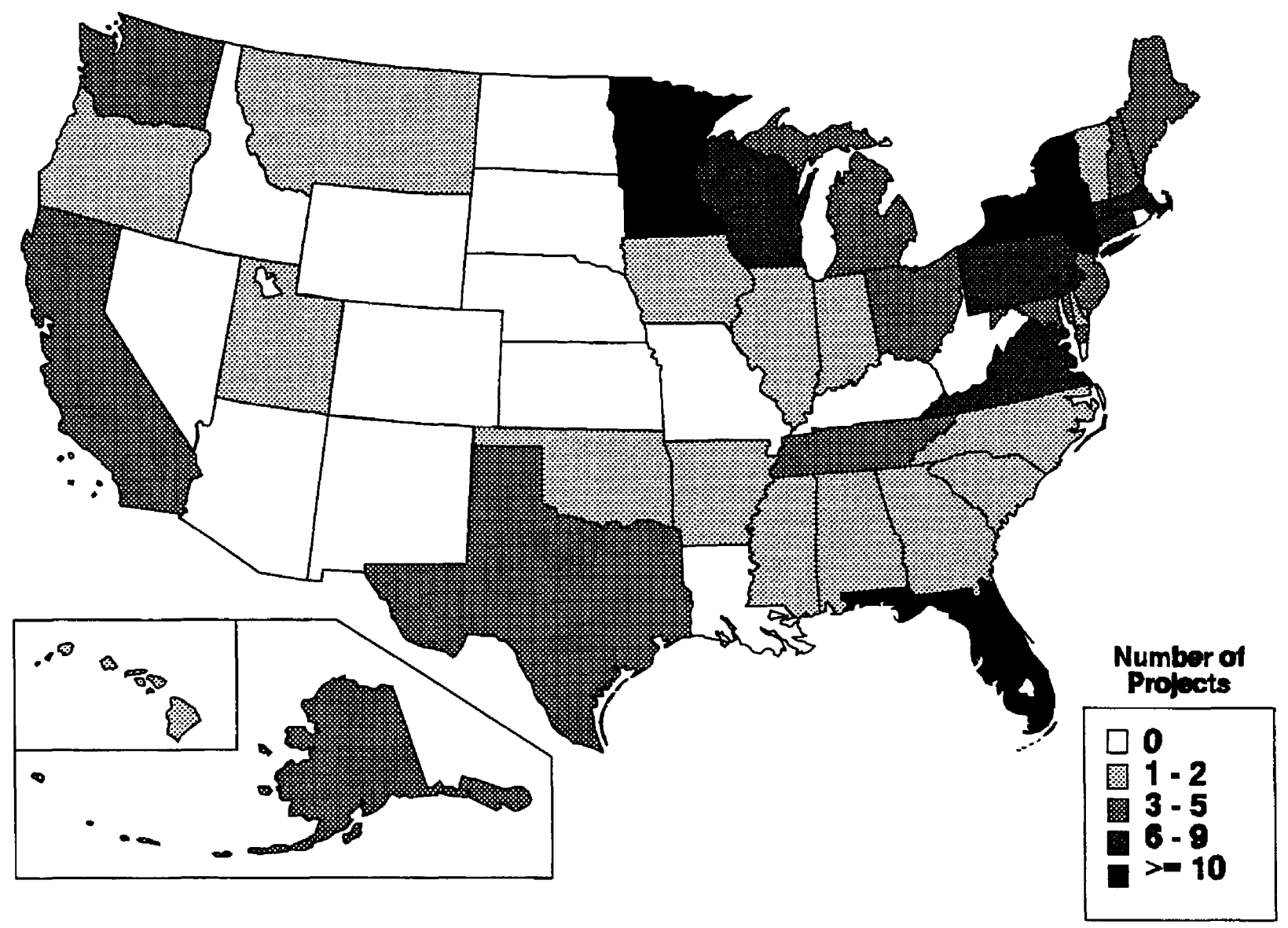

Source: (Berenyi and Gould 1993)

Figure 1-3. Location of waste-to-energy plants by state

WTE plants also have become the target of public and environmental opposition because WTE plants must generally be located close to large sources of municipal waste and, consequently, near large population centers. The 1990 Clean Air Act Amendments direct EPA to regulate emissions of particulate matter (total and fine), sulfur dioxide, nitrogen oxides, carbon monoxide, hydrogen chloride, lead, cadmium, mercury, dioxins and dibenzofurans from WTE facilities (U.S. House 1990). The Amendments also require EPA to base these standards on maximum achievable control technology (MACT), a more rigorous designation than the best demonstrated technology (BDT) standard that EPA had previously used. For new plants, MACT can be no less stringent than the best performing unit. For existing plants, MACT can be no less stringent than the best performing $12 \%$ of existing units (Williams 1991). 
In 1991, EPA issued New Source Performance Standards (NSPS) for WTE plants with individual units exceeding 250 tons-per-day capacity (225 metric-tons-per-day) ${ }^{2}$ (Broom et al. 1993). For plants that began construction after 1989 , the new regulations require emissions control of heavy metals and organic carcinogens by more than $99 \%$, of sulfur dioxide and hydrogen chloride by $90 \%$ to $95 \%$, and of nitrogen oxide by about $40 \%$. For operating plants, the regulations require the control of heavy metal emissions by $97 \%$, of organic emissions by $95 \%$, and of acid gases by about $75 \%$. EPA must also still issue regulations to reduce mercury, lead, and cadmium emissions from WTE plants (Williams 1991). Draft regulations are expected to be published during 1994.

Besides air emissions, concerns have been expressed about the ash produced by WTE facilities. Although the waste combustion reduces MSW volume by $90 \%$, the resulting ash must still be disposed of. Fly ash, which is the ash captured from stack gases, typically has higher heavy metal concentrations than bottom ash, which is the ash that falls to the bottom of the grate or furnace. Bottom ash makes up about $90 \%$ of the total plant ash. Many WTE operators mix the fly and bottom ash before landfill disposal (Williams 1991). A growing quantity of ash from WTE facilities is being managed in ash-only facilities called ash monofills, which incorporate impermeable liners, leachate management systems, and groundwater monitoring, in separate areas of landfills known as ash monocells that are dedicated to ash disposal and equipped with liner and leachate management systems (Berenyi and Gould 1993).

In the past, environmental groups have advocated that WTE incinerator ash be tested for toxicity. If incinerator ash were classified as toxic or hazardous, WTE plant operators could be required to send the ash to a hazardous waste facility, which could raise ash disposal costs sharply. In the 1990 Clean Air Act Amendments, Congress exempted ash from hazardous waste designation for two years, assuming that this issue would be addressed in the reauthorization of the Resource Conservation and Recovery Act (RCRA) in 1992 (Williams 1991). However, Congress did not achieve RCRA reauthorization within this time frame. The U.S. Supreme Court is separately considering the issue. ${ }^{3}$

\footnotetext{
${ }^{2}$ A facility with two units of 170 tons per day (150 metric tons per day) each, for example, would not be affected by these regulations. The EPA regulations classify WTE facilities into two categories: large (unit sizes from 250 to 1100 tons-per-day [225 to 1000 metric tons per day]) and very large (unit sizes over 1100 tons per day [ 1000 metric tons per day]).

${ }^{3}$ The case before the Supreme Court originated in the mid-1980s when the Environmental Defense Fund (EDF) filed lawsuits against Wheelabrator Technologies in New York and the City of Chicago in Illinois. In both cases, EDF requested that toxicity tests be conducted on WTE ash and the waste be managed according to the test results. EDF lost both cases at the district court level and appealed unsuccessfully in New York. In Illinois, however, the U.S. Seventh Circuit Court of Appeals ruled that WTE ash must be managed as a hazardous waste material if it fails a toxicity test. The City of Chicago appealed the ruling to the U.S. Supreme Court. In May 1992, the Supreme Court asked for an issues brief from the Solicitor General of the U.S. Department of Justice, which sought assistance from EPA. EPA ruled that two of RCRA's statutory goals - protecting the environment and promoting resource recovery from non-hazardous waste — are supported by the hazardous waste exemption for WTE ash (Kiser 1992). The Supreme Court declined to hear the case and directed the Court of Appeals to reconsider its decision given the EPA ruling (SW\&P 1993a). In January 1993, the appeals court reaffirmed its original ruling, and in June 1993, the Supreme Court agreed to hear the case (IPR 1993).
} 
With national WTE ash management policy uncertain, some states have set their own standards. A 1989 National Solid Wastes Management Association survey found that $90 \%$ of all states have some type of ash management guideline: $80 \%$ required ash testing before disposal and $74 \%$ had ash-specific landfill design criteria. Nevertheless, there was no consensus among states on how ash should be managed (Kiser 1992b).

Many WTE critics argue that not enough attention is being focused on alternative methods of waste reduction, such as recycling, and that WTE plants encourage growth in garbage to ensure the profitability of these plants. In response, many WTE companies are developing materials recovery services either separately or in conjunction with WTE plants (Charles 1992). Recycling programs will be a component of more than $90 \%$ of WTE plants now planned compared to just over 70\% of existing plants (Berenyi and Gould 1993). Finally, some states have considered moratoriums on WTE projects in favor of emphasizing recycling and regional solid waste management plans. ${ }^{4}$

Because of the increasing difficulties in developing and siting WTE plants, the recent industry trend has been to build larger plants to serve a region rather than a single county or municipality. This trend suggests that these plants will receive waste from a wider geographic area, either countywide or a combination of counties and/or cities, towns, and townships. The gain in design capacity is also attributable to the move toward large, mass-burn incinerators away from smaller, modular units (Berenyi and Gould 1993). However, some industry observers predict that modular units will make a comeback as incremental units for major metropolitan areas that already possess large WTE plants. In addition, increasing emphasis on recycling may decrease the solid waste available for WTE plants, forcing a downsizing in future plants and opening a market niche for smaller, modular plants. Working against modular plants is the high relative cost of complying with more stringent air quality regulations (Williams 1991).

Although several factors point to an industry slowdown, the WTE industry remains optimistic about its future. The industry predicts that recycling will not by itself solve disposal needs and WTE will again appear attractive relative to landfilling (Williams 1991). Even so, market conditions may be rocky given the loss of financial incentives, increasing environmental and regulatory requirements, and the sometimes substantial local opposition to WTE plant development (Berenyi and Gould 1993). Newer plants are incorporating a total system concept that integrates materials recovery with waste combustion, and landfilling of any remaining noncombustible and nonrecyclable materials (Kiser 1993).

\section{Landfill Methane}

Through 1992, 127 plants that recover landfill gas for sale to an end-user or utility were in place in the United States. Another 60 plants are in some stage of planning or development. Of the operating plants, 89 generate electricity and have a total installed capacity of $377 \mathrm{MW}$. Available data suggest that another 192 MW of capacity will be realized from plants under development (HCI 1993).

\footnotetext{
${ }^{4}$ Massachusetts and New Jersey placed temporary moratoriums on WTE plants that have since expired (SW\&P 1991 a; SW\&P 1992b). Moratoriums were proposed, but not adopted, in Florida, Michigan, and Wisconsin (Charles 1992).
} 
Like many renewable energy industries, the landfill methane industry owes its current scale to the passage of PURPA in 1978. Until then, methane gas was largely vented or burned off to avoid explosions at landfills. A few projects producing pipeline-quality gas were in place before PURPA, but project development occurred only slowly. With the advent of PURPA, landfill gas exploitation became more economical for developers. The development of the landfill gas resource for power generation is less costly because lower quality, medium-Btu gas can be utilized. By contrast, projects dedicated to gas sales must clean the gas to pipeline quality (highBtu), which typically involves removing carbon dioxide (Williams and Porter 1989).

The landfill methane industry expanded rapidly through the 1980s, from 32 projects on line in 1984 to 117 projects in 1991 (Berenyi and Gould 1991). Recent activity has been spurred in part by the unconventional fuels tax credit, which is the primary remaining federal tax incentive for the industry. ${ }^{5}$ The credit is tied to the price of oil and equals $\$ 5.53$ per barrel of oil (95.3ø/MBtu) equivalent for 1992 (TB\&A 1993; PFM 1993). Under EPACT, the credit was extended for new facilities placed in service by December 1996. High utility avoided cost rates have also been an industry driver. These rates and a plentiful supply of large landfills have made California and New York the leading states for landfill methane development (Figure 1-4). Other leading states include Illinois, Pennsylvania, New Jersey, Michigan and Wisconsin (Berenyi and Gould 1991).

Avoided cost payments to landfill gas developers under PURPA have declined in conjunction with falling fossil fuel prices. Existing landfill methane plants receive an average buyback rate of $6.18 \notin / \mathrm{kWh}$ but planned facilities will only receive $4.58 \notin / \mathrm{kWh}{ }^{6}{ }^{6}$ Perhaps because of these factors, an increasing number of landfill methane developers are bypassing utilities and selling electricity and/or gas directly to industrial or institutional customers to obtain higher prices. More than a quarter of existing and planned landfill methane facilities are (or will be) selling electricity and/or gas directly to institutional or industrial customers. This trend is particularly apparent in southern and north central states, which have relatively low avoided cost rates, where more than $40 \%$ of projects sell (or will sell) directly to end-use clients (Berenyi and Gould 1991). In other cases, some landfill methane plants are simply closing down because of poor economics (Thorneloe 1992).

New environmental regulations for landfills may surface as a future industry driver. In October 1991, the EPA issued final regulations governing the location, design, and operation of landfills that became effective for most landfills in 1993. The new EPA standards include requirements for omposite liners, leachate collection systems, and groundwater monitoring (SW\&P 1991c). Landfills that cannot meet the new standards must close by October 1996 (SW\&P 1992a). The high cost of complying with the EPA regulations (an estimated $\$ 330$ million annually for 6,000 landfills) will likely force some landfills to close and lead to the development of larger landfills

\footnotetext{
${ }^{5}$ Users of the credit must meet several restrictions. The credit must be used in the year in which the fuel is sold and the credit is decreased in direct proportion to any grants, tax-exempt bonds, or other subsidized financing used to develop the project. The developer must also sell the fuel to an unrelated party. The availability of the credit is generally regarded as critical to the development of landfill methane projects (Williams and Porter 1989).

${ }^{6}$ Based on limited data in (Berenyi and Gould 1991).
} 


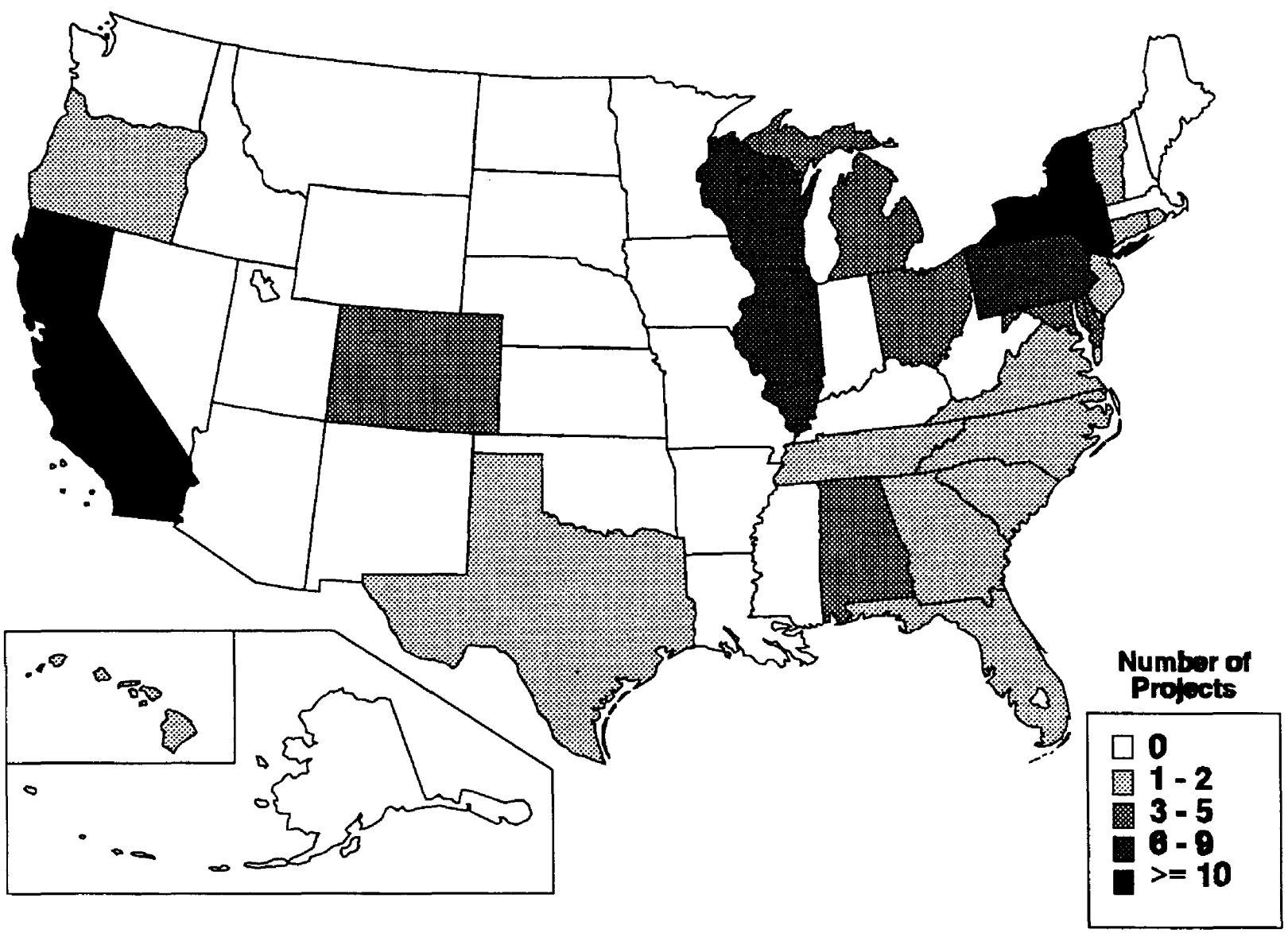

Source: ( $\mathrm{HCl} \mathrm{1993)}$

Figure 1-4. Location of landfill methane power plants by state

to serve regions rather than individual cities or counties (Levin and Smith 1991). This outcome may provide new prospects for landfill methane plants.

Draft EPA regulations have also been issued on emissions of nonmethane organic compounds (NMOCs). NMOCs include benzene and vinyl chloride and contribute to urban smog. It is estimated that solid waste landfills emit about $1 \%$ of the NMOCs released by stationary sources nationwide (SW\&P 1991b). The proposed regulations would require any landfill, existing or new, with a design capacity that exceeds 111,000 tons (101,000 metric tons) and emits 167 tons (150 metric tons) per year of NMOCs, to install gas collection equipment that would remove $98 \%$ of the NMOCs by weight (Levin and Smith 1991). Under the proposed regulations, annual methane emissions from landfills also would be reduced by about $60 \%$ or 10.5 million metric tons per year.

EPA originally estimated that the regulations would affect about 620 existing landfills and 87 new landfills (Levin and Smith 1991). More recently, this estimate has been scaled down to about 200 existing and 15 planned landfills (SW\&P 1993b). Although the regulations might 
result in $\mathrm{CO}_{2}$ and other emissions, such as $\mathrm{NO}_{\mathrm{x}}$, if methane combustion is increased, EPA has noted that net environmental gains would result because of the methane and NMOC emissions reductions that would occur (methane is a more potent greenhouse gas than $\mathrm{CO}_{2}$ ) (USEPA 1991). Although the draft regulations would only require landfill owners to install gas collection equipment, some have speculated that developers might be stimulated to install energy recovery systems to help offset the costs of the collection system (SW\&P 1992c). Final regulations are expected to be issued in 1994 (SW\&P 1993b).

The recently released federal Climate Change Action Plan directs the EPA to formulate a tough rule to reduce methane emissions from landfills in order to increase the amount of organic compounds that must be recovered by landfills and promote additional recovery of methane gas. The plan also directs EPA to launch outreach and technical assistance programs for methane recovery at landfills and coal mines (Clinton and Gore 1993).

Despite the overall environmental benefits, some landfill methane plants have been closed because of state concerns about $\mathrm{NO}_{\mathrm{x}}$ and carbon monoxide emissions (Thorneloe 1992). Developers may face difficulty locating new plants in areas that are in noncompliance with federal standards for one or more of these criteria pollutants (Berenyi and Gould 1991). In most cases, however, public opposition to landfill methane projects is generally minimal and plants are easily sited, especially when the plant will mitigate safety concerns or odor releases from the landfill.

\section{Conclusions}

Of all the renewable energy sources, biomass energy has seen the greatest growth over the last decade. Spurred by PURPA and tax incentives for nonutility generators, biomass-based power generation now provides more than 50 billion $\mathrm{kWh}$ of electric energy from $10,000 \mathrm{MW}$ of installed capacity. The overwhelming majority of this capacity, primarily wood based, has been developed by the nonutility sector.

Biomass power development has not been free from public concerns. The majority of these concerns relate to siting. Several projects that have not succeeded in allaying public concerns have been terminated. Nevertheless, biomass generation is a viable power option. Economic and financial issues presented by slower growth, the reduction of federal incentives, and lower fossil fuel prices present the greatest near-term obstacles to further growth in biomass power development. 


\section{Biomass Combustion and Externalities}

\section{Introduction}

Many of the environmental externalities associated with fuel combustion are a function of the chemical properties of the fuel and the characteristics of the combustion process itself. In this section, we briefly describe and delineate the properties and characteristics of biomass fuels and combustion technologies. We then present information on the types of externalities commonly identified and considered in utility resource planning deliberations and their relationship to biomass-specific characteristics.

\section{Biomass Combustion}

Fuel combustion characteristics vary depending on the specific chemical and physical properties of the fuel as well as the nature of the combustion process. The chemical composition of a solid fuel can be characterized in two different ways. An ultimate analysis refers to the major chemical elements of a fuel based on molecular weights while a proximate analysis describes the relative shares of four constituents: fixed carbon, volatile matter, moisture, and ash. The sum of the fixed carbon and volatile matter represent the combustible fraction of the fuel (Hougan, et al. 1943) Table 2-1 provides comparative chemical analyses of wood, municipal refuse, and coal fuels.

Several general observations can be made from Table 2-1. First, biomass fuels have higher levels of volatile matter and lower levels of fixed carbon. The greater the fixed carbon content, and thus the lower the degree of oxygenation, the higher the heating value of the fuel (Klass 1983). The higher level of volatiles makes biomass more reactive than coal and more amenable to gasification at lower temperatures: $1472^{\circ}$ to $1832^{\circ} \mathrm{F}\left(800^{\circ}\right.$ to $\left.1000^{\circ} \mathrm{C}\right)$ compared with $2400^{\circ}$ to $2600^{\circ} \mathrm{F}\left(1315^{\circ}\right.$ to $\left.1427^{\circ} \mathrm{C}\right)$ (Bain and Overend 1992$)$. Second, the ash content of a typical woody fuel is significantly less than for coal, although the ash content of municipal refuse is higher. Third, the higher moisture content of biomass fuels increases fuel combustion residence time and diverts combustion energy to fuel drying, thus reducing the overall efficiency of fuel combustion (Hollenbacher 1992). Finally, solid biomass fuels are typically low in sulphur content, which results in relatively minor $\mathrm{SO}_{2}$ emissions upon combustion (Bain and Overend 1992).

While the chemical content of a fuel is an important determinant of its environmental emissions characteristics, the efficiency of the combustion process, i.e., the percentage of combustible components converted to energy, is also important. A number of factors influence biomass combustion efficiency such as the amount of air present in combustion, the amount of turbulence to promote fuel mixing, fuel distribution rates and patterns, and fuel moisture content. High ash levels can lead to slagging and fouling in boilers increasing draft losses and impeding heat transfer (Hollenbacher 1992). In the sections that follow, we summarize the key characteristics of biomass combustion technologies and their impact on environmental emissions. 


\begin{tabular}{||l|c|c|c||}
\hline \multicolumn{4}{|c|}{ Table 2-1. Chemical Analysis Comparison of Specific Biomass and Coal Fuels } \\
\hline \hline Analysis & Jack Pine Waste & Municipal Refuse & Bituminous Coal \\
\hline \hline Proximate (\%) & 23.6 & 9.1 & 55.8 \\
\hline Fixed Carbon & 74.2 & 65.9 & 33.9 \\
\hline Volatile Matter & 2.2 & 25.0 & 10.3 \\
\hline Ash & 40.0 & $18.4^{*}$ & $7.3^{*}$ \\
\hline Moisture & & & 75.5 \\
\hline Ultimate (\%) & 53.4 & 47.6 & 5.0 \\
\hline Carbon & 5.9 & 6.0 & 4.9 \\
\hline Hydrogen & 38.6 & 32.9 & 1.2 \\
\hline Oxygen & 0.1 & 1.2 & 3.1 \\
\hline Nitrogen & 0.0 & 0.3 & \\
\hline Sulfur & & & \\
\hline
\end{tabular}

'(Klass 1983)

Sources: Except where otherwise noted: Jack Pine Waste (Hollenbacher 1992); Municipal Refuse/Bituminous Coal (OTA 1980).

\section{Wood and Agricultural Wastes}

As noted in Chapter 2, the majority of biomass power plants are fueled by wood wastes. Utilities operate wood-fired power plants in Vermont, Michigan, Wisconsin, Washington, and Oregon. These plants range in size from 10 to $50 \mathrm{MW}$. A number of nonutility power producers also operate dedicated wood-fired power plants in many states. However, the majority of wood burners encompass some 2000 commercial and industrial facilities that utilize various types of wood wastes for power generation and/or process heat needs. The lumber, wood products, pulpwood, and paper industry are the largest such users of wood for fuel (RTI 1991). Agricultural waste-fueled (ag waste) power plants have had only limited application in the U.S. $\mathrm{Ag}$ waste combustion technologies are similar to wood and wood waste energy technologies, though there are significant differences in fuel handling and combustion characteristics.

In the following subsections, we present an overview of the main technologies for generating power from the combustion of wood and agricultural wastes. The basic differences in approach relate primarily to the design of the combustion chambers, the operating temperature, and the heat transfer mechanism (Klass 1983).

\section{Direct-Fired Steam Turbine Technologies}

Biomass-fired steam turbine power generation technology is very similar to the technology utilized in conventional fossil-fuel power plants. The biomass fuel is combusted in a boiler to 
produce steam that drives a turbine and generator. Both the low density and low heating value of biomass, relative to coal, require that the combustion area be oversized relative to a coal firebox for a given power output. Most biomass-fired steam cycle plants utilize single-pass steam turbines. However, improved design features, such as reheat and regenerative steam cycles and supercritical steam turbines, have been transferred from larger scale steam turbine generators (USDOE 1992). Direct-fired steam technologies include pile burners, stationary or traveling grate combustors (spreader-stoker firing), and atmospheric fluidized-bed combustors (bubbling and circulating beds).

Pile Burners. Pile burners were very common fifty years ago for burning wood waste. The typical pile burning combustor had multiple refractory-lined cells. Each cell had a lower combustion chamber, like a dutch oven with a grate floor, and an upper combustion chamber. Most of the fuel was burned on the grates, while the volatiles were burned in the secondary combustion zone. Ash was removed manually from the furnace by shutting down a cell, allowing it to cool, and removing the ash by breaking it up and taking it from the furnace.

The primary advantages of pile burners were simple design, low construction costs, and the capability of handling high moisture content wood mixed with dirt. Disadvantages included lower efficiencies relative to other biomass combustion technologies, the need to periodically shut down cells for cleaning, and a combustion process that was very difficult to control. Pile burners are available today that have improved combustion processes and control and automatic de-ashing systems. However, the degree of environmental emissions control is less than that available in other biomass direct combustion technologies (Hollenbacher 1992).

Grate Combustors. Grate combustors have fuel feeders that evenly distribute the biomass over a traveling or stationary grate where the fuel burns. An air chamber is located beneath the grate, which supplies the air through the grates to the fuel. With a stationary grate, ashes are dumped into a pit, while a traveling grate rotates so that the ashes are conveyed and discharged into an ash hopper (USDOE 1992).

The traveling grate stoker is relatively insensitive to load swings, thus providing greater load control than the stationary grate. Different furnace wall configurations have been developed for the traveling grate stoker to be used in conjunction with various overfire air schemes to promote more complete combustion. In order to meet $\mathrm{NO}_{\mathrm{x}}$ emission standards in the $1980 \mathrm{~s}$, manufacturers designed a staged combustion process. This process increased overfire air levels from approximately $20 \%$ to $50 \%$. Modern traveling grate boilers can be designed to handle various fuels; however, they have limited fuel switching capability because of their design. Traveling grate boilers have exhibited few slagging problems with biomass fuels. An example of a traveling grate boiler system is the Honey Lake Power Co. plant in Wendel, California (Hollenbacher 1992).

A third type of spreader stoker that has gained popularity since the $1950 \mathrm{~s}$ is the sloped reciprocating water-cooled grate or Kablitz grate. Design advantages include simplicity, inherent low fly ash carryover characteristics, and low maintenance because of fewer moving parts (Hollenbacher 1992). 
Suspension-Fired Boilers. Suspension-fired boilers are a very recent development for biomass combustion and are somewhat comparable to pulverized coal-fired boilers. In these boilers, combustion occurs while fuel particles are pneumatically suspended in an air stream. To date these boilers have had only limited application for biomass because of the additional cost of fuel preparation; suspension firing requires an elaborate fuel preparation and feeding system for proper combustion.

Several different fuel burners have been developed for suspension-fired boilers, including the scroll-type, register fuel/air mixture, cyclonic burners, and vertical cylindrical burners. In a suspension-fired boiler, air and fuel are mixed in a turbulent environment to promote complete combustion. Because of the potential explosion hazard created by dry, fine fuel particles, suspension-fired fuel handling systems require more careful design than conventional biomass fuel handling systems (Hollenbacher 1992). An example of current suspension-fired boiler design is Oxford Energy's 28.7-MW facility in Williams, California, which is fueled by rice residues.

Co-Firing. In addition to dedicated combustion, wood waste can be co-fired with fossil fuels. Co-firing can provide benefits in terms of emissions reductions and local economic development. However, because of differing fuel characteristics, extensive wood fuel preparation or boiler modifications may be necessary at higher wood fuel input levels to avoid boiler efficiency degradation, depending on the type of boiler; cyclone boilers are more tolerant of fuel differences than pulverized coal boilers (Tillman et al. 1993). Co-firing of wood in pulverized coal boilers (the most common boiler type) generally requires some drying of the wood and pulverizing with the coal, or addition of a dump grate to facilitate combustion of the larger wood feedstock sizes (Wiltsee et al. 1993). Cyclone boilers can accept larger size fuel particles and higher moisture contents (up to 50\%) because the cyclone slagging process enhances fuel residence time and thus more complete combustion (Tillman et al. 1993).

The Tennessee Valley Authority has recently conducted case study analyses of wood co-firing, at up to $15 \%$ heat input, in several of its coal-fired boilers and concluded that conditions at numerous plants may be favorable for wood co-firing (Tillman et al. 1993).

\section{Fluidized-Bed Combustors}

In fluidized-bed combustion, wood is injected into the combustion chamber through ports and burned in suspension. Air fluidizes a bed of hot, granular material, such as sand, which mixes with the wood. Fuel particles are dispersed throughout the bed, where they are quickly heated to ignition temperature. Because of the turbulence, the combination of air, sand, and wood resembles a boiling liquid that has excellent heat transfer properties. Since operating temperatures are typically below $1700^{\circ} \mathrm{F}\left(927^{\circ} \mathrm{C}\right)$, thermally induced nitrogen oxides are minimized. The staged combustion also minimizes fuel-bound nitrogen oxide formation. Fluidized-bed combustors can handle many different types of fuels such as high-ash wood waste, agricultural residues and slow burning char, although with some performance degradation (USDOE 1992).

There are two types of fluidized-bed combustors: bubbling (BBC) and circulating (CFBC). The distinguishing feature is the velocity of air through the unit. In bubbling beds the velocity is 5 
to $12 \mathrm{ft} / \mathrm{s}(1.5$ to $4 \mathrm{~m} / \mathrm{s})$, while in CFBC it is up to $30 \mathrm{ft} / \mathrm{s}(9 \mathrm{~m} / \mathrm{s})$. The CFBC technology has the following advantages over bubbling bed: increased combustion efficiency, improved absorption of acid gases, less prepared fuel and sorbent, and elimination of feeding problems by the use of underbed or overbed feeding systems. Disadvantages of CFBCs are the need for greater fan horsepower to maintain higher velocity through the bed and higher capital costs in small sizes (15 to $30 \mathrm{MW}$ ) (Wiltsee et al. 1993).

Three CFBC companies have operating U.S. projects. Gotaverken Energy Systems has two 25MW plants in California that burn wood and agricultural waste. The design moisture specification is very dry (20\% to $45 \%)$ when compared to conventional wood burning plants (40\% to 55\%). A 25-MW, CE-Lurgi CFBC is operating in Fresno, California, which is fueled by urban wood waste, in-forest residues, and agricultural waste. This design can handle fuels with moisture contents ranging from $8 \%$ to $60 \%$, very low to high fuel densities, and heat contents from 6500 to $9500 \mathrm{Btu} / \mathrm{lb}(15$ to $22 \mathrm{MJ} / \mathrm{kg}$ ). The third design, B\&W-Studsvik CFBCs, utilizes primarily wood chips. Three units are in operation, one in California and two in Maine. Several CFBCs experienced fuel fouling problems in the first year of operation. High sodium and potassium levels, such as those found in almond and pistachio shells, can defluidize the bed, so that when the boiler is cooled down, the agglomerations freeze into a solid, slag-like mass that must be manually removed (Hollenbacher 1992).

Several bubbling bed combustors were built in the United States in the early 1980s to fill a market niche for low air emissions and a low cost, smaller sized power plant. Several bubbling bed manufacturers later modified their designs to fit between the traditional bubbling bed design and the CFBC. The fluidization velocities were increased, thus increasing the combustion recycle rate and providing for higher fluid bed combustion loadings.

JWP (formerly EPI) has been the major proponent of the bubbling bed design. The first such project was a utility boiler retrofit (15 MW) in Wisconsin in 1981. As of 1991, JWP also had five biomass-fueled BBC power plants in California ranging in size from 12 to $32 \mathrm{MW}$. These plants burn a variety of fuels including urban wood waste, agricultural wastes, and wood residues. Yanke Energy Inc. designed and built two 9-MW BBC power plants in California using modified and reconditioned boilers and steam turbine-generators. These plants utilize mill wastes, forest slash, and hogged urban wood waste. Both of the plants use ammonia injection to control nitrogen oxides to meet strict California emission requirements (Hollenbacher 1992).

\section{Advanced Technologies}

Whole Tree Burning. Whole tree burning is a relatively new concept, currently under development, designed primarily to reduce wood harvesting and handling costs. Feedstock size limitations are determined by the dimensions of the furnace wall opening where whole logs are fed into the furnace. Other than a saw located at the furnace wall opening, no fuel processing equipment is utilized. Waste heat is used to dry the trees before combustion, reducing average moisture content from about $50 \%$ to under $25 \%$. Whole tree combustion occurs in three phases: combustion of tree piles at $1093^{\circ} \mathrm{C}$ in which the wood is volatilized into hot gases with unburned char falling into grates; high temperature combustion of the volatile gases at $1482^{\circ} \mathrm{C}$ above the logs; and low temperature combustion of the char below the bed. Flue gases from the 
combustion process are used to reduce the feedstock moisture content. With the waste heat utilization, overall power plant efficiency is projected to range from $33 \%$ to $36 \%$, compared to $20 \%$ to $30 \%$ for conventional wood power plants. The heat rate for the entire system is estimated to be about $10,000 \mathrm{Btu} / \mathrm{kWh}(10.5 \mathrm{MJ} / \mathrm{kWh})$, as compared to 12,000 to 16,000 $\mathrm{Btu} / \mathrm{kWh}$ (12.5 to $17 \mathrm{MJ} / \mathrm{kWh}$ ) for conventional wood power plants (Chupka et al. 1992).

Direct-Fired Gas Turbine. A direct-fired gas turbine burns shredded biomass fuel with compressed air. Particulates are removed from the gas stream and the clean gases are then expanded through the turbine portion of the gas turbine. One design produces both electricity and thermal energy with efficiencies around $70 \%$. This technology has been tested at the pilot scale in both the U.S. and Canada. However, a number of technical issues still need to be resolved, including pressurized fuel feeding and ash removal, gas stream cleanup and turbine blade fouling (USDOE 1992). A 3-year demonstration project has been initiated by the Western Research Institute with cofunding from DOE and Power Generating, Inc. (McCarroll and Partanen 1993).

Biomass Gasification/Gas Turbine. Thermal gasification is a two-step, endothermic process in which biomass is thermochemically converted into a low or medium Btu gas. The first reaction is pyrolysis where volatile components of the fuel are vaporized at temperatures below $600^{\circ} \mathrm{C}$. Char and ash remains as the non-vaporized by-products of pyrolysis. The second process, char conversion, gasifies and/or burns the carbon that remains after pyrolysis. In this reaction, some char is burned to provide heat for pyrolysis and the remaining char is gasified. Much of the technology for biomass gasification is adapted from coal gasification (USDOE 1992).

Converting biomass into a gas provides the opportunity to integrate biomass gasifiers with simple cycle, combined cycle, or steam-injected gas turbines. Overall conversion efficiency is increased through the use of both the thermal and chemical energy of hot product gases in the power cycle. Air-blown fixed-bed and fluidized-bed gasifiers are the preferred options for biomass gasification. Oxygen-blown gasifiers produce higher-Btu gas and faster reaction rates than air-blown systems, but they also have higher capital costs because of the oxygen requirements (USDOE 1992). A number of small-scale, biomass gasifier systems are being operated in the United States today, designed to produce low-Btu gas as a substitute fuel or for steam cycle electricity production (Bain and Overend 1992). Additional biomass gasifier systems are currently being developed under DOE sponsorship.

Fixed-Bed Gasifiers. When compared to other air-blown gasifier designs (fluidized-bed, entrained flow) the fixed bed provides the largest fraction of gas energy in chemical form. In one type of fixed-bed design, the updraft gasifier, biomass is fed from the top of the gasifier, then undergoes drying, pyrolysis, char gasification, and char combustion as it settles to the gasifier bottom. The product gas is removed from the top of the gasifier and ash is removed from the bottom. Blast air and steam are injected into the gasifier to keep the ash above melting temperatures and to facilitate char conversion.

The product gas from this process has a low velocity and temperature and a high heating value. However, the low operating temperature creates a large amount of condensable oils and tars in the product gas, which may pose difficulties with hazardous waste disposal. The filtering effect 
of the bed and low stream velocities create a product gas with low particulate concentrations. The volatility of biomass combined with the excellent heat transfer design and high peak temperatures in the fixed-bed design provide for a carbon conversion efficiency of around $99 \%$ and a hot gas efficiency that ranges from $90 \%$ to $95 \%$. Fixed-bed gasifier design and operation are relatively simple but require large, dense, uniformly sized fuels (USDOE 1992). There is little practical operating experience with the fixed-bed design.

Fluidized-Bed Gasifiers. Like the fluidized-bed combustor, a fluidized-bed gasifier uses a continuous feed of biomass and an inert heat-distributing material, such as sand, which is "fluidized" by an oxidant and/or steam. Pyrolysis and char conversion take place throughout the bed and are not localized. The superior mixing in the fluidized-bed provides excellent heat and mass transfer, which yield uniform temperatures, better fuel-moisture utilization, and faster reactions. These benefits allow higher throughput capabilities that can reduce the size and capital cost of the gasifier relative to other types of gasifiers. Because the average temperature in a fluidized bed is greater than in a fixed bed, more tars and oils are converted into permanent gases. Product gas composition, carbon, and hot gas efficiency for the fluidized-bed process are similar to fixed-bed designs. Fluidized-bed designs can handle smaller, less dense, and less uniform feedstocks. The major difficulty with the fluidized-bed design is the high particulate level in the raw gas, which is nearly 100 times greater than in the fixed-bed design (USDOE 1992).

Gasifier/Gas Turbine Power Cycles. High-efficiency gas turbines have been developed utilizing superior clearance control and advanced compressor and turbine blade design. These simple cycle gas turbines have reached power generation efficiencies of around 36\%. A fluidized-bed gasifier coupled with a high-efficiency gas turbine may be an attractive future option for simple cycle operation (USDOE 1992).

Combined cycle plants with power efficiencies approaching $50 \%$ could be a viable option for intermediate or base load operation. The steam-injected gas turbine (STIG) is an adaptation of the combined cycle in which the turbine exhaust gases are used to generate steam in a heat recovery steam generator. Steam is injected into the combustor and/or turbine sections of the gas turbine. The steam injected into the turbine provides additional mass to help drive the turbine, yet does not consume power from the turbine's compressor. Also, more power can be taken from the turbine section because the specific heat of the steam-air mixture is twice that of air. Adding steam in the combustion zone lowers flame and gas temperatures and prevents up to $80 \%$ of uncontrolled $\mathrm{NO}_{\mathrm{x}}$ formation (USDOE 1992).

The addition of compressor intercooling to the STIG cycle (intercooled STIG or ISTIG) can raise thermal efficiency and shaft power output. The ISTIG can double the output of a simple gas turbine, raising the overall power efficiency to more than 50\%. One shortcoming of STIG cycles is the cost of the large quantity of demineralized water, which is consumed by the system and released to the atmosphere. Complete recovery of the water could be accomplished for a modest capital investment and incremental penalty on heat rate (USDOE 1992).

Biomass Pyrolysis. Biomass pyrolysis produces an oil that can be used in gas turbines or for cofiring in existing pulverized coal- or oil-fired boilers. An important advantage of pyrolysis oils 
for power production is that they could be transported to power plant sites more cost effectively than the biomass feedstocks.

Pyrolysis is performed by applying heat to prepared biomass feedstocks that are usually less than 2-mm thick and have less than $8 \%$ moisture content. The biomass particles are thermochemically converted to a mixture of non-condensable gases, char particles, pyrolysis oil vapors, and water vapor. The particle residence time must be kept under two seconds so the pyrolysis oil vapors will not chemically transform into permanent gases or more viscous polymers. After leaving the reaction chamber, the various constituents flow through a cyclone separator where particulates are removed. The pyrolysis oil vapors are then condensed to form a black, viscous, medium Btu mixture of organic compounds. Sixty to eighty percent of the feedstock is converted to biomass fuel oil. The residual noncondensable gases can be collected downstream from the condenser and burned to provide process heat to dry the feedstock or heat the reactor (USDOE 1992).

There are three primary types of pyrolysis reactor designs: vortex, tubular transport, and fluidized bed. In the vortex reactor design, a carrier gas (steam or nitrogen depending on the fuel oil application) and a dry feed ( $1 \%$ to $2 \%$ moisture content) are injected into a cylindrical reaction chamber. The fuel enters the reactor in a spiral pattern over the inside surface of the cylinder where it is heated. Partially pyrolyzed particles and char exit the reactor tangentially, while the gaseous product is separated and flows to cyclones. Particles that are removed tangentially are recycled to the carrier gas stream and enter the reactor for a second time. Recycling of the particulates provides the following advantages: reduced char levels, ability to pyrolyze larger feedstocks (up to $3 \mathrm{~mm}$ ), and a different residence time for solid particles and vapors. The end product consists of $67 \%$ pyrolysis oil, $13 \%$ char, and $14 \%$ net pyrolysis gases. The char and non-condensable gases are burned to provide process heat for drying and the pyrolysis.

The tubular tranșport reactor design uses a thermal mixer and a tubular transport reactor to convert biomass to a liquid fuel oil. A solid heat carrier, externally heated by residual char, noncondensable pyrolysis gases, or another source, is fed into a thermal mixer with processed biomass. The biomass undergoes an extremely rapid temperature increase in the thermal mixer. Total residence time for the biomass particle is below one second. The heat transfer medium and biomass are then fed into the tubular transport reactor where the biomass is decomposed. Typical yields from this design are $75 \%$ pyrolysis oil and equal amounts of char and noncombustible gases (10\% to $15 \%$ ).

In the fluidized-bed design, an inert material and the biomass are supported by steam, flue gas, or non-condensable vapors. Biomass is fed from the top or side of the fluidized-bed reactor, with the product gas taken from the top. Reactor temperature ranges from $450^{\circ}$ to $500^{\circ} \mathrm{C}$ and feedstock residence time is from 2 to 8 seconds. Liquid yields are from $65 \%$ to $80 \%$ of the feedstock.

Biomass pyrolysis R\&D has been conducted on a small scale, involving four primary organizations: the National Renewable Energy Laboratory (NREL) and Georgia Tech University in the United States and the University of Waterloo and ENSYN Engineering in Canada. Remaining technical issues include (1) potassium and other trace metals from the oil can form compounds during combustion which can plate hot gas-path components; (2) pyrolysis oil can 
polymerize when heated; and (3) because pyrolysis oil is acidic, special materials must be utilized for the product storage tanks (USDOE 1992).

\section{Waste-to-Energy}

Because of land and environmental concerns, landfill disposal of municipal solid waste (MSW) has become increasingly problematic. As a result, many communities have encouraged the development of waste-to-energy projects. There are four primary pathways for converting waste into energy: (1) mass burning, (2) production of refuse-derived fuel, (3) biological digestion, and (4) pyrolysis (MRI 1988).

The average composition of MSW by weight in the United States is approximately $70 \%$ organic matter and $30 \%$ inorganic matter. Paper, at 37\%, represents the largest fraction of MSW, followed by yard waste $(18 \%)$, metal and glass $(15 \%)$, plastic $(8 \%)$, food wastes $(7 \%)$, wood $(6 \%)$, miscellaneous materials, which include leather, rubber and textiles $(5 \%)$, and inert materials (4\%) (Brower et al. 1993). MSW composition can vary widely due to the season, the socioeconomic characteristics of the local population, and the amount and type of commercial and industrial waste. The average moisture content of MSW is around $25 \%$, but this can vary considerably with the weather. A waste-to-energy plant must be designed for the full range of MSW delivered to the plant, not just the average composition (Richards et al. 1990). The average Btu content for MSW can vary from 4450 gross Btu/lb (10 MJ/kg) for MSW to 7660 gross Btu/lb (18 MJ/kg) for RDF.

\section{Mass Burn}

Mass burn systems combust solid waste as received. In newer facilities, the waste generally goes through a pre-combustion processing step to remove recyclable materials. There are two general size classifications of mass burn systems: (1) field-erected systems, which are usually medium to large scale (200 to 3000 tpd [180 to 2700 metric tons per day]), and (2) factory fabricated (modular) systems, which are smaller scale (up to 300 tpd [270 metric tons per day]) (Richards et al. 1990). The trend has been away from modular systems because of the high cost per unit size of environmental controls. Both refractory-lined and water wall furnaces have been used in mass burn systems. Refractory-lined furnaces recover heat downstream of the furnace using a waste heat boiler. A variation of the refractory-lined furnace uses modular starved-air combustors, which consist of a refractory-lined furnace with a deficient supply of combustion air, followed by a second-stage chamber to finish the burning, and a heat recovery boiler to generate steam. Water wall furnaces use both water walls in the combustion chamber and convection back pass tubes for heat recovery and steam generation. The combustion of MSW takes place on moving grates (MRI 1988).

\section{Refuse-Derived Fuel}

Refuse-derived fuel (RDF) systems improve the fuel properties of MSW by pre-processing the fuel to reduce particle size, remove noncombustibles, and homogenize the fuel. Strictly speaking, however, RDF is any fuel product that results from the processing of municipal solid wastes. Besides solid fuel, RDF can also include liquid and gaseous fuels that are derived from the chemical or biological conversion of processed waste materials. 
Most of the commercial experience with RDF in the United States has been with "coarse" and "fluff" solid RDF materials. Coarse RDF is a shredded MSW material while fluff RDF undergoes additional processing to produce a low ash, fluffy material that has a heating value close to western lignite. It is usually less than 2.5 inches ( 6 centimeters) in size, with most of the noncombustibles removed (MRI 1988).

RDF combustion can be accomplished in dedicated boilers or by co-firing with fossil fuels in existing utility boilers. Between 1972 and 1988, nine U.S. utilities co-fired almost 1 million tons (900,000 metric tons) of RDF with the RDF accounting for, on average, $10 \%$ of the total fuel requirements, by thermal input. Only four of the nine utilities continue to co-fire RDF with coal: Ames (Iowa) Municipal Electric Co.; Madison (Wisconsin) Gas \& Electric; the Lakeland (Florida) Department of Electric and Water Utilities; and Baltimore (Maryland) Gas \& Electric. The other five utilities discontinued the RDF co-firing for various reasons, mostly economic (SRI 1992). Since this time, two additional utilities, Otter Tail Power (South Dakota) and Northern States Power (Minnesota), have initiated RDF co-firing.

Because RDF is a lower quality fuel than the fossil fuels usually burned in utility boilers, RDF co-firing can negatively affect power plant performance and operation. The higher ash content of RDF increases slagging and fouling of the boiler as well as the amount of boiler ash that must be treated and disposed of. The slagging reduces heat transfer and thus plant efficiency and increases operation and maintenance costs for the boiler. For a new plant specifically designed for coal and RDF, co-firing RDF at $15 \%$ heat input can reduce boiler efficiency by $1.5 \%$ to $2.5 \%$, compared to dedicated coal combustion; in a retrofitted unit, efficiencies can drop by up to $3.5 \%$ (SRI 1992).

The primary issue involved in RDF co-firing is whether the potential operational disadvantages can be offset by fuel cost savings and emissions reductions (e.g., $\mathrm{SO}_{2}$ ) compared to the use of conventional fossil fuels. While the performance record for RDF co-firing has been spotty, many of the operational problems have been surmounted through evolutionary improvements in RDF fuel quality and plant design improvements such as bottom ash dump grates.and the avoidance of high heat-release boilers that are prone to slagging (SRI 1992).

By far, the greatest use of RDF, representing more than $650 \mathrm{MW}$ of gross generating capacity, is in dedicated boilers using spreader-stoker technology. ${ }^{7}$ In a spreader stoker, the RDF is burned partially in suspension, with the non-combustibles dropping to the traveling grate or stoker. The long residence times of this process allows for more complete combustion of the RDF fuel. A recent survey of 16 operating RDF production facilities using semi-suspension firing found that these plants operate at an average 92\% of design capacity (SRI 1992).

\section{Biological Digestion}

Refuse landfills produce various gaseous by-products. Anaerobic bacteria, which thrive in an oxygen-free environment such as a covered landfill, promote organic decomposition. This

\footnotetext{
${ }^{7}$ Although dedicated to RDF combustion, these boilers may also employ alternate fuels such as coal, natural gas, or other biomass fuels.
} 
decomposition produces landfill gas (LFG), which typically consists of $55 \%$ methane, $44 \% \mathrm{CO}_{2}$, and $1 \%$ assorted trace gases. The $\mathrm{CO}_{2}$ is soluble in water and generally leaches out of the landfill. Methane remains in the gaseous phase and tends to migrate up from the landfill. Methane is flammable and volatile and can cause explosions at concentrations as low as $5 \%$ to $15 \%$. Control strategies include venting the methane to the atmosphere, flaring, or other types of combustion. With the enactment of PURPA and various tax incentives, landfill gas recovery and combustion for electricity generation became more prevalent (Williams and Porter 1989).

Methane gas is recovered by drilling wells to a depth of 30 to 100 feet ( 9 to 30 meters) and piping the gas to a central collection facility where the gas is extracted by utilizing industrial compressors. The gas also can be cleaned through a filtering system. A 30-acre (12-hectare) landfill, containing 1 million metric tons of solid waste to a depth of 40 feet (12 meters), will generate enough gas to fuel a 1-MW turbine (Williams and Porter 1989). The average heating value of raw LFG is around $490 \mathrm{Btu} / \mathrm{scf}$ (Berenyi and Gould 1991).

\section{Pyrolysis}

Pyrolysis technologies also can be utilized to convert MSW to gaseous or liquid fuels. The status of these technologies has been described previously (see Wood and Agricultural Wastes).

\section{Anaerobic Digestion of Animal Wastes}

Animal wastes can be converted to biogas by anaerobic digestion. In 1987, U.S. farm animals produced some 42 million tons ( 38 million metric tons) of collectable waste, which is equivalent to 0.3 quads of thermal energy per year. Biogas from animal waste has a heating value of around $600 \mathrm{Btu} / \mathrm{ft}^{3}\left(22 \mathrm{MJ} / \mathrm{m}^{3}\right)$, with a methane content of $60 \%$, and a $\mathrm{CO}_{2}$ content around $40 \%$. Biogas can be directly combusted to provide space or process heat, as a boiler heating fuel, or to power engines to generate electricity.

Anaerobic digestion biologically converts animal wastes to a gas in the absence of oxygen. This process occurs in two phases. During the first phase, acid-forming bacteria convert carbohydrates, fats, and protein in the wastes to simple acids. In the second phase, the organic acids are converted by methane-forming bacteria to methane, $\mathrm{CO}_{2}$, and small amounts of ammonia and hydrogen sulfide. The methane-forming bacteria are extremely sensitive to oxygen, temperature, $\mathrm{pH}$, and the feedstock loading rate. These factors must be carefully controlled to balance methane formers with acid formers. One limiting step of digester operation is that the methane-forming bacteria require four or more days to produce methane.

Digesters are airtight containers that can either be batch or continuously loaded. A concrete/steel vessel or covered lagoon can be used. Concrete/steel vessel digesters have been used in the United States because they are readily available. However, covered lagoon systems are becoming more popular because they are less expensive, easier to operate, and require less maintenance. The process starts with the flushing of manure into a holding pit. The waste is mixed, and if necessary, solids are removed with a separator. The slurry is pumped to a grit removal chamber, then into the reactor where anaerobic conversion takes place. The reactor is maintained at a constant liquid level with a temperature of at least $60^{\circ} \mathrm{F}\left(15^{\circ} \mathrm{C}\right)$. Biogas is pumped through a 
special membrane to where it can be used as a fuel. The remaining waste product is treated and stored in a holding pond to be used as fertilizer (RTI 1991).

Because of their high capital costs combined with low avoided cost rates in many states, anaerobic digesters are currently not economically viable for bulk power generation, except under special circumstances where waste disposal costs are high (RTI 1991). However, digester systems can provide for farm-specific energy needs, such as fuel for a boiler or furnace, refrigeration (utilizing an absorption chiller), or on-site electricity generation with an enginegenerator set (Safley and Lusk undated).

More than 20 methane recovery systems are operating at private and university livestock centers across the country. Anaerobic digester systems may have high potential in areas with a welldeveloped agricultural and livestock economy. In North Carolina, for instance, it has been estimated that anaerobic digesters installed at one-third of the large swine farms in the state could displace the equivalent of nearly $5 \%$ of the state's average natural gas consumption. Other important side benefits of these systems include reduced water pollution potential, deodorization, pathogenic threat control, and the fertilizer and animal feed by-products (Lusk 1993).

\section{Biomass Externalities}

Externalities, as considered in utility resource planning, generally relate to the environmental impacts of power generation or the combustion process itself. Also important, however, are externalities that may occur over the entire fuel cycle, from fuel harvesting to combustion byproduct waste disposal. Economic externalities, such as local job creation, may also be considered. A final type of externality relates to the risk of overreliance on fuel sources that may have uncertain price streams, supply availability, or environmental characteristics. We present a brief survey of these issues below.

\section{Generation Externalities}

The primary generation-related externalities of interest in utility resource planning proceedings are air emissions. Secondary considerations relate to water quality, solid waste disposal, and land use.

\section{Air Emissions}

Several different residual products are formed during the biomass combustion process. $\mathrm{NO}_{\mathrm{x}}$ formation from biomass combustion is generally low because biomass contains relatively low amounts of fuel bound nitrogen. Thermal $\mathrm{NO}_{\mathrm{x}}$ formation is highly dependent on temperature and oxygen concentration. Minimizing $\mathrm{NO}_{\mathrm{x}}$ formation is dependent on the ability to control flame temperatures below the diatomic disassociation level $\left(\sim 1700^{\circ} \mathrm{F}\left[\sim 925^{\circ} \mathrm{C}\right]\right)$ (Hollenbacher 1992). Because of the relatively low sulfur content of most biomass fuels, there is very little $\mathrm{SO}_{2}$ formation during combustion. Biomass combustion-related $\mathrm{SO}_{2}$ emissions are expected to be well below even the more stringent $\mathrm{SO}_{2}$ controls enacted in the 1990 Clean Air Act Amendments (Bain and Overend 1992). Furthermore, the potential exists to cofire biomass fuels with fossil fuels, primarily coal, in existing plants as an $\mathrm{SO}_{2}$ reduction strategy. 
The most problematic combustion-related air emissions for biomass are particulates, volatile organic compounds (VOCs), and toxics. Although uncontrolled biomass combustion can lead to relatively high particulate emissions, these emissions can be reduced substantially through the use of stack removal technologies such as fabric filters or electrostatic precipitators (Bain and Overend 1992). VOCs are an ozone precursor with the relative importance of their impact dependent on regional, seasonal and other factors (Ottinger, et al 1990).

Non-methane organic compounds (NMOCs) are primarily volatile organic compounds that can be emitted from landfills; the methane in the landfills acts as a transport gas for NMOCs into the atmosphere. NMOC levels and composition differ greatly by landfill, and actual levels cannot be determined until test wells are measured. Tests have shown NMOC concentrations to range from $237 \mathrm{ppm}$ to $14,294 \mathrm{ppm}$ at selected landfills with concentrations affected by the quantity, age, $\mathrm{pH}$ level, and composition of the refuse, as well as the moisture content of the landfill and whether the landfill has previously accepted hazardous waste. NMOCs can be removed from landfill gas through gas collection systems or gas combustion (USEPA 1991).

Waste-to-energy plants may emit a wide variety of air pollutants including dioxins, furans, cadmium, lead, chromium, mercury, arsenic, and nickel, as well as more well-known air pollutants like sulfur oxides, hydrogen chloride, nitrogen oxides, hydrogen fluoride, particulate matter, carbon monoxide and carbon dioxide (Ottinger, et al. 1990). Increasingly, federal and state regulations are requiring waste-to-energy plants to control these pollutants. Indeed, wasteto-energy plants are among the first industrial emission sources to be regulated for heavy metal and toxic organic pollutants. With emissions control equipment, waste-to-energy plants typically remove more than $90 \%$ of hydrogen chloride; more than $99 \%$ of particulate matter; more than $85 \%$ of sulfur dioxide; and between $35 \%$ and $69 \%$ of nitrogen oxide emissions, depending on the control strategies used. Although data are limited, some plants remove between $90 \%$ and $99 \%$ of heavy metals and $99 \%$ of toxic organics (Gaige and Halil 1992).

An important air emissions characteristic of most biomass resources is that net carbon dioxide or methane emissions can be very low or even negative. Trees and plants absorb $\mathrm{CO}_{2}$ during growth, offsetting $\mathrm{CO}_{2}$ emissions released in combustion. Landfill methane projects can recover methane, a potent greenhouse gas, that might otherwise be released to the atmosphere (Roos et al. 1993). And waste-to-energy plants can also provide a greenhouse gas benefit by avoiding future methane and $\mathrm{CO}_{2}$ emissions from landfills (Brower et al. 1993).

Biomass combustion systems can also provide offsets for air emissions from other combustion sources. For example, wood waste combustion can provide air emissions benefits if the wood waste would have been burned as forest slash. One study concluded that a wood cogeneration plant would result in about one-tenth the level of particulate, VOC, and polycyclic organic compound emissions, somewhat less carbon monoxide, and about the same level of nitrogen oxides emissions as open burning of the same amount of wood waste (Eco Northwest 1986). The development of landfill gas systems can serve as a mitigation measure for controlling methane emissions; methane is a greenhouse gas which, molecule for molecule, is approximately 20 times more harmful as a global warming agent than carbon dioxide. Worldwide, landfills are estimated to contribute from $3 \%$ to $10 \%$ of total methane emissions (Ottinger et al. 1990). 


\section{Solid Waste}

All fuel combustion results in ash by-products that require disposal. Woody biomass materials have a lower ash content than coal, while MSW has a higher ash content. At the present time, both biomass and coal ash are classified as non-hazardous (USDOE 1992). Ash from wood power plants is often utilized as a liming agent for acidic soils in agriculture and silviculture. In Maine, half of the wood ash generated by power plants is used in this fashion (Brower, et al. 1993). Such beneficial uses of wood ash are expected to increase as the physical, chemical, and environmental characteristics of wood ash become better understood (Fehrs and Donovan 1993).

Ash from waste-to-energy facilities includes "fly ash" captured in air pollution control equipment and residues found in the combustion chamber, or "bottom ash." About 8.5 million tons (7.5 million metric tons) of ash are produced annually by waste-to-energy facilities (Kiser 1992a). Concerns have been raised about the presence of heavy metals, dioxins, and furans in ash from waste-to-energy facilities, and the potential for leaching of these materials from ash contained in landfills (Ottinger et al. 1990). However, recent studies suggest that ash from waste-to-energy plants may not be hazardous (Kiser 1992a). ${ }^{8}$

\section{Water Use}

Significant amounts of water are required for cooling in thermal power plants. As long as waste water is non-hazardous, it can be handled by municipal water treatment plants. In general, the water cooling requirements for biomass and coal power plants are comparable (USDOE 1992).

\section{Land Requirements}

Land requirements considerations generally pertain to the amount of land occupied by a power plant facility and its adjoining infrastructure. There are no significant differences in the land requirements of biomass and fossil generation plants (Feher 1984). However, also important is how the land will be utilized and how this use relates to adjacent land use as well as land zoning.

\section{Total Fuel Cycle Externalities}

To date, environmental externalities considerations have primarily addressed emissions from power generation. However, some observers have argued that power generation externalities should be viewed from a total fuel cycle perspective; that is, the entire production cycle of a fuel should be examined, from the mining or harvesting of the raw material, through transportation and power generation, to waste disposal. Biomass resources generally have fewer "back end" externalities than fossil fuels. For example, biomass combustion can provide waste reduction benefits as well as offsets for air emissions from other combustion sources, particularly for $\mathrm{CO}_{2}$.

\footnotetext{
${ }^{8}$ Studies cited by Kiser note that the use of lime to control acidic gas air emissions hardens the ash and creates a cement-like mixture with little leaching or run-off potential. In addition, the dioxins and furans sometimes found in the ash become physically bound and thus are not released when the ash is disposed of. Finally, some studies have found that the levels of heavy metals in ash leachate from monofills are close to drinking water standards and lower than the toxicity criteria used by EPA.
} 
However, less clear are the comparative "front end" externalities associated with the biomass feedstock, particularly if the industry moves to dedicated feedstock production. Dedicated biomass energy cropping can potentially reverse local ecosystem degradation, such as soil erosion, if it substitutes for traditional intensive agricultural production (Hughes and Ranney 1993). On the other hand, some ecologists have expressed concern about the potential impact of bioenergy cropping on biodiversity if conducted in more diverse natural habitats (Hoffman et al. 1993). ${ }^{9}$ Ultimately, the nature and magnitude of these impacts will be a function of how carefully larger scale, energy-dedicated biomass production is implemented (Hughes and Ranney 1993).

At the present time, there does not appear to be a great inclination among the states to examine externalities on a total fuel cycle basis. Externalities at the plant site, such as combustion emissions, are easier to quantify and regulate, while externalities beyond the plant site may be more difficult to quantify. Also, total fuel cycle externalities may transcend state and regional boundaries.

Nevertheless, some state commissions have considered the issue of total fuel cycle externalities. In Massachusetts for example, the Department of Public Utilities (DPU) has noted that as it becomes more experienced with assessing externalities values from power plants, it would consider proposals to expand the focus to earlier stages of the fuel cycle on a case-by-case basis (MDPU 1990). And in Oregon, the Public Utilities Commission (PUC), after consideration, also decided not to set external cost estimates for upstream or downstream fuel cycle impacts, other than air emissions, but left the door open for future consideration (OPUC 1993).

\section{Economic Externalities}

Studies have attempted to measure the economic benefits of biomass facilities. The U.S. Department of Energy estimates that the $6500 \mathrm{MW}$ of wood-fired power plant development have generated more than 66,000 jobs, $\$ 10$ billion in capital investment, more than $\$ 460$ million in federal and state taxes, and $\$ 1.8$ billion in personal and corporate income in 1992 (USDOE 1993a). Other studies have examined regional or local economic benefits of biomass facilities. For example, it has been estimated that, in 1985, every 1000 tons (900 metric tons) of wood energy consumed in the Northeast resulted in an average of 1.96 jobs and $\$ 46,634$ of personal income (COPM 1990). It has been estimated that, in the Southeast, every 1000 tons (900 metric tons) of black liquor consumption by industrial facilities in 1987 created $\$ 11,152$ of net income and 0.77 jobs, while every 1000 tons (900 metric tons) of fuel wood created $\$ 23,942$ of net income and 1.39 jobs (TVA 1990).

Public entities receive royalties from the extraction of methane in landfills. Pacific Energy, which has developed 25 landfill methane projects, has paid out $\$ 13$ million in royalties, mostly

\footnotetext{
${ }^{9}$ Hoffman et al. note that large-scale biomass plantations, if not carefully implemented, "could displace significant natural vegetation and wildlife habitat, and reduce national and global biodiversity." They contend that "biomass plantations are typically envisioned as monocultures that will be intensively managed for maximal production" and as such "will have greatly reduced plant species diversity, and will probably provide good habitat for only a fraction of the fauna that would occupy the site with its natural vegetative cover."
} 
to public entities. In addition, the company bought more than $\$ 4$ million in outside goods and services for its projects in 1991, and it has a annual payroll exceeding $\$ 3$ million (Thorneloe 1992). A recent study of renewable energy options in the Midwest region estimates that woodfired power plants utilizing dedicated, short-rotation woody crops as a feedstock would produce more jobs than coal-fired plants of equivalent capacity (Brower et al. 1993).

Despite these studies, few states have attempted to consider in-state economic development in resource planning decisions. Because the relative contribution of different types of projects to economic development is difficult to quantify, these considerations, where required, have tended to be very general. However, in Nevada, utilities are required to calculate economic benefits based on: "(a) capital expenditures for land and facilities located within the state or equipment manufactured in the state; (b) the portion of the cost of materials, supplies, and fuel purchased in the state; (c) wages paid for work done within the state; (d) taxes and fees paid to the state or subdivision thereof; and (e) fees paid for services performed within the state" (NPSC 1991).

Some states have decided explicitly not to include local economic impacts of energy technologies in externalities calculations, among them Oregon and Wisconsin. The Massachusetts DPU considers economic and social externalities (e.g., local job creation and support) as transfer payments instead of resource costs and declined to include local job creation in their externalities values (MDPU 1990). It has also been argued that economic impacts do not constitute true market externalities; that is, the direct impacts from employment and earnings, as well as indirect impacts, are already reflected in the market price of electricity from a power generating facility (Sanghi 1991). Finally, it has also been noted that a state may not realize significant employment and economic benefits unless it imports most of its fossil fuels (Brower et al. 1993).

\section{Fuel Risk Externalities}

Generally, a broad mix of fuel and resource types will provide diversity in utility power supply and reduce the risks associated with overreliance on any one particular fuel type. These risks may come in the form of fuel price escalation, fuel supply interruptions, or future regulatory changes. Some states have attempted to explicitly account for the value of fuel diversity in resource planning considerations. For example, in California, the PUC has determined that protecting against "the financial risks of relying too much on a given fuel" is important but has yet to devise a methodology to accomplish this. For this reason, the PUC established a set-aside to acquire some new generating capacity from renewable energy resources as an interim measure to achieve fuel diversity (CPUC 1991; CPUC 1992).

At the same time, the Bonneville Power Administration (BPA) has stressed the importance of anticipating "adverse business risks" in resource decisions. These risks include "mandatory control and equipment retrofits; future regulatory constraints on operations or fuel use; taxes imposed on emissions, fuels, carbon, or other substances; court challenges from unsuccessful energy suppliers or public policy advocates; and responsibility to mitigate environmental damage occurring in other phases of the fuel cycle because of BPA's financial ability to do so" (Buchanan 1992). 


\section{Conclusions}

Many of the environmental externalities associated with fuel combustion are a function of the chemical properties of the fuel and the characteristics of the combustion process itself. For instance, woody biomass fuels generally have low sulfur and ash content, thus minimizing $\mathrm{SO}_{2}$ emissions and ash disposal requirements, but their low fixed carbon and high moisture content means that these fuels have a relatively low heating value. Biomass power technologies may differ significantly in their combustion efficiencies. The basic differences relate primarily to the design of the combustion chambers, the operating temperature, and the heat transfer mechanism. Several advanced technology concepts offer the potential for increased combustion efficiencies and thus reduced combustion-related externalities.

Air emissions have received the greatest amount of attention in externalities deliberations. Although all new power generation plants must meet prevailing emission performance standards, utility resource choices may increasingly be impacted by how much a particular project can improve on the prevailing standard. While some states have attempted to consider economic and fuel risk externalities as well, these considerations are not well developed at present. 
TP-5789

\section{Trends in State Externalities Consideration}

\section{Introduction}

Increasingly, states are factoring the environmental and socioeconomic impacts of energy resource and technology choices into electricity resource planning and procurement decisions. Over onehalf of the states incorporate externalities in some form in the planning process and several other states are currently considering it. This section introduces the different methodological approaches being utilized by the states and assesses the degree to which externalities consideration is actually impacting resource decisions.

\section{Externalities Consideration}

In recent years, integrated resource planning (IRP), or least-cost planning, has developed as a more comprehensive process for addressing electricity planning uncertainty. An important aspect of IRP is the consideration of a broader array of factors that may impact future utility operating conditions. Among these many factors are non-market-related environmental and social concerns, or "externalities." In economics, a market externality occurs when some of the costs (or benefits) of a market transaction are borne (or received) by parties not directly involved in the transaction (Nicholson 1978). These externalities, therefore, represent costs or values that may not be directly reflected in the market pricing of the transaction.

Although externalities could encompass a wide variety of costs or values not captured by market transactions, such as ancillary economic development that may occur because of resource or technology choices, states have initially focused on environmental externalities, especially air emissions from power plant operations. Some examples include health or aesthetics-related damage from air emissions or the market and business risks of potential regulatory controls of greenhouse gases. In 1992, 29 states had existing requirements to consider externalities in resource planning and/or acquisition; six states and the District of Columbia were considering adopting externalities requirements; six states had considered externalities but had not imposed requirements; and 10 states had not yet addressed the externalities issue (See Table 3-A at the end of this section).

\section{Approaches to Incorporating Externalities}

Several different approaches have been used to integrate externalities concerns into utility resource planning (Cohen et al. 1990b). The most direct approach is the monetization of environmental externalities. However, this direct quantification of externalities costs has met with considerable controversy. A primary issue is whether control costs or damage costs are used. Control costs represent the additional costs of equipment to control emissions to some specified level, while damage costs are estimates of the actual damage caused by environmental emissions. Although most analysts agree that the use of actual environmental damage costs is preferable, these costs are very difficult to estimate and may also be subject to revision over time (Buchanan 1990; Freeman et al. 1992). For this reason, emission control costs are often used as a proxy. 


\begin{tabular}{||l|c|}
\hline \multicolumn{2}{|c|}{$\begin{array}{c}\text { Table 3-1. Values for Environmental Factors } \\
\text { Applied to a Coal Plant in New York }\end{array}$} \\
\hline \hline Environmental Factor & $\mathbf{c / k W h}$ \\
\hline \hline Air Emissions & $\mathbf{0 . 9 0 5}$ \\
\hline Sulfur Oxides & 0.250 \\
\hline Nitrogen Oxides & 0.550 \\
\hline Carbon Dioxide & 0.100 \\
\hline Particulates & 0.005 \\
\hline Water Discharges & $\mathbf{0 . 1 0 0}$ \\
\hline Land Use Impacts & $\mathbf{0 . 4 0 0}$ \\
\hline \hline Total Externalities & $\mathbf{1 . 4 0 5}$ \\
\hline
\end{tabular}

Source: (NYDPS 1989)

An example of the monetization of environmental externalities by the state of New York, based on cost of control, is provided in Table 3-1. Values were adopted for residual air emissions, i.e., emissions given compliance with state and federal air quality standards, as well as water and land impacts. The chart shows that the valuation of residual environmental impacts would theoretically add $1.4 \notin / \mathrm{kWh}$ to the cost of coal-fired generation.

The comparative value of environmental externalities can differ markedly among states. For example, the calculated value of externalities for a new coal plant meeting federal new source performance standards (NSPS) can vary from the $1.4 \varnothing / \mathrm{kWh}$ in New York to over $4 \varnothing / \mathrm{kWh}$ in Massachusetts and Nevada (Wiel 1991). A large portion of this disparity is due to the valuation of $\mathrm{CO}_{2}$ emissions. Table 3-2 compares the $\mathrm{CO}_{2}$ externality values adopted by six states. While New York values $\mathrm{CO}_{2}$ emissions at $\$ 1 /$ ton, other states value these emissions at from $\$ 8$ to $\$ 22 /$ ton. The higher values are based on the estimated cost of tree planting as a $\mathrm{CO}_{2}$ mitigation measure while the lower value in New York was adopted as a "social cost of $\mathrm{CO}_{2}$ emissions" in lieu of a control cost value (Biewald and Bernow 1992; NYDPS 1989). Clearly, the treatment of $\mathrm{CO}_{2}$ emissions is a key aspect of direct externalities valuation.

Table 3-3 presents NREL estimates of resource- and technology-specific environmental externalities values using state-adopted externalities values for air emissions, and standard technology emission factors and heat rates documented in Table 3-B. ${ }^{10}$ The table illustrates a wide range in state-adopted monetized externalities values. For example, the calculated externalities values for a pulverized coal plant range from $0.6 \notin / \mathrm{kWh}$ in New York to $4.0 \notin / \mathrm{kWh}$ in Massa-

\footnotetext{
${ }^{10}$ Because states have developed generic emissions values in dollars per ton, the $\phi / \mathrm{kWh}$ conversion depends on fuel and emission control characteristics and will vary among individual plants.
} 


\begin{tabular}{||l|c|}
\hline \multicolumn{2}{|c|}{$\begin{array}{c}\text { Table 3-2. Comparative Externality Values } \\
\text { Adopted for } \mathrm{CO}_{2} \text { Emissions }\end{array}$} \\
\hline \hline State & $\$ /$ ton \\
\hline \hline New York PSC & 1.1 \\
\hline California PUC/CEC & 8.0 \\
\hline New Jersey BPU & 14.1 \\
\hline Wisconsin PSC & 15.0 \\
\hline Nevada PSC & 22.0 \\
\hline Massachusetts DPU & 22.9 \\
\hline
\end{tabular}

Sources: (Biewald and Bernow 1992) and (WPSC 1992)

chusetts and Nevada. ${ }^{11}$ The wide disparity reflects the different values for certain air pollutants adopted in each state. The magnitude of the externalities adders for biomass depends on whether biomass is penalized for $\mathrm{CO}_{2}$ emissions. To date, Massachusetts is the only state that has explicitly adopted a greenhouse-neutral policy for biomass resources, although Nevada has also formally considered the issue. ${ }^{12}$ With a full $\mathrm{CO}_{2}$ offset, the externalities adder for a wood project in Massachusetts is lowered from more than $5 \notin / \mathrm{kWh}$ to about $1 \notin / \mathrm{kWh}$, which is less than natural gas combined cycle plants that are considered to be the cleanest fossil fuel option. In those states that do not provide for $\mathrm{CO}_{2}$ offsets, the externalities adder for wood projects can be as high as $5 \notin / \mathrm{kWh}$.

Landfill methane projects can have an externalities adder ranging from $1 \not / \mathrm{kWh}$ to $3 \notin / \mathrm{kWh}$. However, landfill methane plants collect and utilize methane gas that might otherwise escape into the atmosphere. If values are applied for methane reduction, landfill gas plants can have a negative total externalities value, i.e., the value of the methane reduction more than offsets the penalties assessed for $\mathrm{SOx}, \mathrm{NOx}$, and $\mathrm{CO}_{2}$ emissions. Three of the five states currently value methane emissions but do not allow negative values to be applied. Similarly, waste-to-energy (WTE) proponents have argued that WTE plants should receive an externalities credit for avoid-

\footnotetext{
${ }^{11}$ The California value represents PUC-adopted values for attainment areas. Other values calculated for California range as high as $10.2 \varnothing / \mathrm{kWh}$ for nonattainment areas in the Southern California Edison (SCE) and San Diego Gas \& Electric (SDG\&E) service territories.

${ }^{12}$ The Massachusetts Department of Public Utilities (DPU) has ruled that $\mathrm{CO}_{2}$ values will apply to "net, rather than gross, emissions of $\mathrm{CO}_{2}$ for facilities using renewable fuels, including wood, wood wastes and crop residues . . to the extent that the fuel supply is sustainably managed," provided that "the developer [must] prove that the fuel supply lot is replanted annually with biomass of $\mathrm{CO}_{2}$ sequestration potential equal to the value of the reduction stated [in the power purchase contract]" (MDPU 1991). In the Nevada externality rulemaking, the PSC noted that "live biomass respiration can displace some of the emissions of wood burning facilities," and "the use of municipal solid waste and wood waste in electricity generating facilities can displace emissions from decomposition in landfills." The PSC recommended that developers attempt to quantify these offsets. However, staff at both the New York and Wisconsin Commissions have expressed support for $\mathrm{CO}_{2}$ offsets for wood-based fuels (Putta 1993; lliff 1993).
} 
Table 3-3. Representative Environmental Adders for States with Monetized Externalities ${ }^{13}$ (cents/kWh, \$1992)

\begin{tabular}{|c|c|c|c|c|c|}
\hline Fuel - Technology & California & Massachusetts & Nevada & New York & Wisconsin \\
\hline Coal - Pulverized (NSPS) & 2.2 & 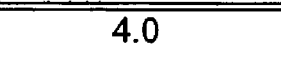 & 4.0 & $\overline{0.6}$ & 1.7 \\
\hline Coal - AFB & 1.7 & 3.7 & 3.6 & 0.3 & 1.8 \\
\hline Coal - IGCC & 1.0 & 2.5 & 2.5 & 0.2 & 1.4 \\
\hline Natural Gas - Combined Cycle & 0.7 & 1.5 & 1.4 & 0.1 & 0.7 \\
\hline Natural Gas - Combustion Turbine & 1.1 & 2.4 & 2.4 & 0.2 & 1.2 \\
\hline Wood - Steam & 1.9 & $5.2 / 0.9$ & $4.8 / 0.7$ & $0.3 / 0.1$ & $2.7 / 0.1$ \\
\hline Biomass - Advanced Gasification & 1.2 & $3.0 / 0.3$ & $3.0 / 0.3$ & $0.2 / 0.1$ & $1.7 / 0.1$ \\
\hline Municipal Solid Waste & 1.8 & 4.9 & 4.7 & 0.3 & 2.2 \\
\hline Landfill Methane & 1.7 & $3.2 /-2.8$ & $3.0 /-2.9$ & 0.4 & $1.0 /-2.7$ \\
\hline Geothermal - Flashed Steam & $<0.1$ & NA & $<0.1$ & NA & NA \\
\hline Solar - Trough with Gas Backup & 0.7 & NA & 1.8 & NA & NA \\
\hline
\end{tabular}

$\mathrm{NA}=$ not applicable

ing landfill waste disposal and its associated emissions (Taylor 1990). However, no such credit is assumed for WTE plants in Table 3-3.

The way in which monetized externalities values are applied also differs among states. In Massachusetts, the values are applied directly to the economic cost of proposed generation sources in resource evaluation and competitive bidding processes. In New York, the externalities values have been used to develop weights for "non-price" factors in the state's competitive bidding procedure; the non-price component has typically accounted for about $25 \%$ of the total project scoring. Finally, in Nevada, the PSC established default externalities values to be used in the comparison of the "societal costs" of resource options in utility resource planning. ${ }^{14}$ In addition to these three states, California uses monetized values for residual air emissions in utility resource planning and the state's competitive bidding process in an effort "to balance many electric resource planning objectives along with environmental quality" (CPUC 1992). The values are applied to both new and existing resources. ${ }^{15}$

\footnotetext{
${ }^{13}$ All externalities values were calculated using standardized technology assumptions and emissions factors (see Table 3-B at the end of this section). The variation in total externalities values among these states is largely an artifact of different $\mathrm{CO}_{2}$ emissions values (see Table 3-2). The California numbers represent PUC-adopted values for attainment areas, i.e., those areas in Clean Air Act compliance; values for nonattainment areas are higher. For wood and advanced biomass, the first value represents total externalities without $\mathrm{CO}_{2}$ offsets credit and the second value with $\mathrm{CO}_{2}$ offsets for those state commissions that have explicitly considered offsets or in which commission staff have expressed support for $\mathrm{CO}_{2}$ offsets. For landfill methane, the second value represents a credit for methane emissions reductions for those states that have monetized methane emissions; however, none of these states currently allow negative values to be applied. Externalities values for noncombustion renewables would be zero.

${ }^{14}$ However, the state's utilities are not obligated to use these values if they can justify different values. Both of the state's utilities, in subsequent resource plan filings, have recommended values equal, on average, to $10 \%$ or less of the PSC values based on ratepayer willingness to pay studies (Henderson 1992).

${ }^{15}$ For one utility, the application of the externality and fuel diversity considerations has advanced its period of resource need by eight years (Walther and Jurewitz 1992).
} 
A second method that has been utilized to implement externalities considerations in the states is a percentage adder approach in which the cost of "dirtier" resources is increased by some arbitrarily determined percentage to reflect the cost of residual environmental damages. Conversely, "cleaner" resources may receive a percentage cost credit based on their environmental benefits. This method was first implemented in the Northwest Power Act of 1980, under which conservation measures were to receive a $10 \%$ cost credit. In at least one case in the Northwest, this $10 \%$ cost credit has been extended to renewable energy sources as well. ${ }^{16}$

Adders may also serve as proxy values to be used in resource planning pending the development of more definitive values. In 1989, the Wisconsin PSC adopted a $15 \%$ cost credit for noncombustion-based generation sources in resource planning as an "interim step" to account for air emissions externalities pending the development of more advanced quantitative methods (Cohen et al. 1990a). And in 1990, the Vermont PSB adopted a 5\% environmental adder to supply-side resources "as an initial proxy for their unpriced environmental harm," pending further analysis of the external costs of different supply options (VPSB 1990).

Finally, the majority of states that have incorporated externalities into resource planning require utilities to consider externalities in a qualitative manner. These "orders" range from fairly superficial treatment in planning to explicit weighting in resource procurement decisions. For instance, in Michigan, utilities have been asked to quantify environmental risks in scenario modeling for their integrated resource plans. In Ohio, the PUC assesses whether utilities have qualitatively considered environmental impacts and costs in reviewing an integrated resource plan. And in Delaware and Utah, environmental impacts are used only for illustrative purposes and do not factor into resource decisions.

\section{Externalities Issues}

Several important issues have been raised concerning the application of externalities in electricity resource planning and procurement. First, electric utilities represent only one source of pollution emissions, albeit a large one. Concern has been expressed that electric utilities are being singled out for treatment when externalities should be addressed across the entire energy system (Browne 1991a). In its order instituting the use of externalities values, the California PUC stated that "our measured actions are designed with the recognition that the utility sector of our economy is only one contributor (and not the largest contributor) to the state's air quality problems" (CPUC 1990).

Second, many externalities orders address only residual air emissions when energy use has environmental and social impacts across the entire fuel cycle from mining and harvesting to waste disposal. ${ }^{17}$ Third, concerns have been expressed that the application of externalities to prospective plants only may actually degrade air quality by providing an incentive for utilities to operate older, dirtier units rather than build new, cleaner plants. For this reason, it has been suggested that externalities values be applied to existing plants as well (Sutley and Works 1992).

\footnotetext{
${ }^{16}$ Puget Sound Power and Light extended the $10 \%$ cost credit to renewables in its 1991 request for proposals for $100-$ $200 \mathrm{aMW}$ of long-term resources (Swezey 1993).

${ }^{17}$ See, for example, the discussion in (MDPU 1990).
} 
Others recommend that utilities dispatch generating resources based on lowest total cost, including environmental externalities (Bernow et al. 1991). Opponents of this approach argue that generation costs would rise under environmental dispatch as generation from lower cost, older units was displaced by new, cleaner units with higher direct operating costs, or if older units were prematurely retired. Also, environmental dispatch might require plants with higher emissions, designed for baseload operation, to be cycled on a regular basis, incurring efficiency and performance losses (Browne 1991b). While full environmental dispatch may still be years away, some elements are already being practiced. For instance, the Clean Air Act Amendments of 1990 , by restricting the total sulfur dioxide $\left(\mathrm{SO}_{2}\right)$ emissions available to the utility sector, provides an impetus for utilities to utilize low $\mathrm{SO}_{2}$ emitting units. And local regulations in southern California require utilities to dispatch generation units on a low $\mathrm{NO}_{\mathrm{x}}$ basis (Sutley and Works 1992).

Finally, concerns have been expressed that if electricity rates rise with externalities valuation, a state's economic competitiveness may be negatively impacted relative to other states. Furthermore, industrial customers may choose to self-generate or physically relocate their production facilities (Joskow 1992). As a consequence, some states have been cautious in the valuation of externalities for competitiveness reasons. For example, in establishing its lower value for $\mathrm{CO}_{2}$ emissions, the New York PSC wrote that because of "the wide disparity between these estimates as well as existence of some controversy surrounding the need for controlling $\mathrm{CO}_{2}$ emissions .... I It is staff's view that before New York State decides to charge itself the full amount for its $\mathrm{CO}_{2}$ emissions, it should be assured that other states and countries are also acting to resolve this problem" (NYDPS 1989). More recently, the Oregon PUC has requested that the state's utilities identify and assess the impact of any customer switching to unregulated fuels or other suppliers as a result of its externalities policy (OPUC 1993).

The authority of state utility regulatory agencies to act in this area has also been questioned. In some states, such as Nevada, the regulatory commissions have been guided by state law. However, in other states, utility regulatory agencies have encountered obstacles in pursuing externalities policies. For example, the Wisconsin PSC's non-combustion credit was overturned in state court, in a case brought by several of the state's utilities for being more stringent than established state emissions limits. On the same grounds, Wisconsin utilities have sued to nullify a commission decision to monetize emissions values for greenhouse gases. In Massachusetts, the authority of the DPU to set externalities values has similarly been challenged in the courts. And in Oregon, an informal opinion has been rendered that the PUC lacks the authority to require utilities to monetize externalities.

Finally, in 1992, the California state legislature passed legislation restricting future application of externalities requirements in utility resource planning and acquisition. The legislation exempts utilities from externalities requirements if market-based emissions trading has been implemented in the utility's service territory and limits the advancing of a utility's resource need based on externalities considerations (Barakat and Chamberlin 1993).

It has been argued that there are more cost-effective strategies of mitigating environmental impacts than monetizing externalities or setting emission-specific limits and using command and control strategies to meet those limits (Joskow 1992; Sutley and Works 1992). In this regard, 
three approaches have been advanced: the use of emissions fees, under which polluters must pay a fee for all measured emissions of a specific pollutant; tradeable emission allowances, under which a pollution emissions cap is established and polluters must obtain allowances for emissions ${ }^{18}$ and offset requirements, under which new sources of pollution must reduce, or offset, existing emissions from other sources or purchase offsets from another entity. The offset system is similar to that for tradeable emission allowances, except that there is no formal designation and allocation of allowances.

A number of states that have monetized environmental externalities did so before the enactment of the $\mathrm{SO}_{2}$ trading system in the 1990 Clean Air Act Amendments, and some states are revisiting the externalities issue to assess the impact of this and other federal policy changes. Although recently reaffirming the use of monetized values, the Massachusetts DPU now allows an emitter to forgo the use of externalities values for $\mathrm{SO}_{2}, \mathrm{NO}_{\mathrm{x}}$, and VOCs if it has secured full offsets (MDPU 1992). In addition, parties can substitute offsets for emissions that are not yet regulated, such as $\mathrm{CO}_{2}$, methane, or nitrous oxides, or for pollutants where there are no federal or state offsite reduction provisions in effect, as long as the off-sites are certified by the Massachusetts Department of Environmental Protection.

Wisconsin also allows utilities to use offsets, such as tree planting or forest protection, to partly or fully substitute for the carbon dioxide, nitrous oxides, or methane values adopted by the state (WPSC 1992). And both Nevada and New York have opened proceedings to revisit their externalities values, at least partly to assess the impacts of the Clean Air Act and the Energy Policy Act of 1992.

Other federal actions may prompt some states to assess whether certain externalities are already being internalized. For instance, President Clinton has pledged to reduce U.S. greenhouse gas emissions to 1990 levels by the year 2000. The President's Climate Change Action Plan calls for voluntary utility commitments to reduce greenhouse gas emissions (Clinton and Gore 1993). The Energy Policy Act of 1992 also requires the U.S. Department of Energy to conduct a national inventory of greenhouse gas emissions and to issue guidelines for voluntary reporting of emissions reductions by any measure, including renewable energy investments or purchases.

It is not yet clear how much impact externalities rulemakings will have on electric resource decisions, particularly for biomass resources, since some of the states that have monetized externalities have not yet made resource decisions utilizing these considerations. Early indications are that the advantages biomass and other renewables may receive from externalities considerations may not be enough to overcome the competitive disadvantages renewables face from low-cost fossil fuels and the perceived higher risk of renewable energy technology investments.

\footnotetext{
${ }^{18}$ Under such a scheme, emissions allowances, or permits, are allocated equal to the cap. New emissions sources must obtain allowances either by buying allowances on the open market or by reducing emissions from existing sources to free up allowances. The Clean Air Act Amendments of 1990 utilize a tradeable emissions system as the mechanism to achieve $\mathrm{SO}_{2}$ reductions.
} 
In New York, for example, results from the first round of competitive bidding indicate that the consideration of environmental attributes has had the general effect of favoring the selection of natural gas-based projects over coal-fired projects. Out of nearly 1,000 MW of winning projects, only one biomass-based project, a $17.7 \mathrm{MW}$, waste-wood-fired plant, was selected. In fact, this was the only renewables project of any type selected. These results have raised questions in New York over the interplay of environmental and fuel diversity considerations in the bidding process (NYSEO 1991). In 1991, Boston Edison was the first utility to solicit new capacity under the Massachusetts externalities order. The utility received 40 bids totaling 3,000 MW, including two wood projects, a solid waste project, and a wind plant. None of these projects finished higher than 18th in the project selection rankings (BECO 1992).

Although the relative impact of externalities considerations on the prospects for renewables is unclear, a number of states and utilities have taken other actions to stimulate renewables. These include the use of "green RFPs," utility incentives, and renewables set-asides. In 1991, the New England Power Company, a subsidiary of New England Electric System, issued a renewablesonly (or "green") RFP, to place "a limited number of renewable and waste electric power production facilities into commercial operation to assess the current-day feasibility, value, resource potential, and environmental attributes of renewable resource technologies" (NEP 1991). In response, the utility company received 41 project bids representing 1400 million $\mathrm{kWh}$ of annual generation, seven times the requested amount. Of the 41 projects bid, 7 projects were biomass, 10 landfill methane, 1 waste-to-energy, 7 small hydro, 7 wind, 4 photovoltaic, and five others. Final selection included four landfill gas projects and the waste-to-energy project out of seven total projects. These biomass-based projects were selected, in part, for their environmental benefits, such as reduction of waste and greenhouse gases (Hachey 1993).

More recently, Portland General Electric has released an RFP for up to 50 average MW (or 100 to 200 nominal $\mathrm{MW}$ ) of renewables-based generation as a mechanism to "acquire a limited number of projects of diverse and proven renewable technologies into commercial operation" and "to demonstrate the cost-effectiveness of renewable energy resources, as well as their commercial viability" (PGE 1993a). Five projects, including two biomass projects, were chosen for further negotiations (PGE 1993b).

At the state level, the Wisconsin Public Service Commission recently approved a renewables incentive program of $0.75 \notin / \mathrm{kWh}$ for qualifying wind and solar-based generation and $0.25 \phi / \mathrm{kWh}$ for all other qualifying renewables-based generation (biomass, hydro, waste-to-energy, landfill gas, and tire-derived fuel). The incentive is available for 20 years for both utility-owned and utility-purchased renewables generation from new projects that are placed in operation or receive construction authority by the end of 1998 (WPSC 1993).

Under California law, the state's three investor-owned utilities must set aside a portion of their capacity need for renewables, to be acquired through competitive bidding (CPUC 1992). The bidding was conducted during the second half of 1993. A similar set-aside, for $300 \mathrm{MW}$, was established in New York as a component of the state's 1992 State Energy Plan (NYPSC 1992). Under a recent settlement agreement, the state's utilities will pursue development of between 303 MW and 387 MW of renewable energy-based projects. Nearly two-thirds of this total will involve biomass resources (NYPSC 1993). And in Minnesota, recent legislation has established 
a state preference for renewable energy generation as a utility's first choice of new power supply. The law states that "the commission shall not approve a new or refurbished nonrenewable energy facility in an integrated resource plan or a certificate of need ... nor allow rate recovery (for such facility) ... unless the utility has demonstrated that a renewable energy facility is not in the public interest" (MN 1993).

\section{Conclusions}

The consideration of externalities in utility resource planning is still in the formative stages. Furthermore, much of this activity has been focused on establishing the relative attractiveness of demand-side management options vis-á-vis supply-side options, primarily fossil fuel plants. Less well developed are externalities comparisons of renewable energy options with traditional fossil fuel-based options. In fact, our investigation has found very little consideration of renewables in this context. Those comparisons that have been performed generally relate to the evaluation of emissions from projects proposed in competitive bidding solicitations. These bid evaluations are often confidential and thus have not yielded much public information on the relative environmental impacts of utility resource options.

States are increasingly considering environmental and other socioeconomic externalities as part of the electricity resource planning and acquisition process. However, both the methods utilized and the scope of these considerations differ widely. The treatment of greenhouse gas emissions and the credits or penalties ascribed to biomass-based projects, will be a key determinant of the comparative externalities standing of biomass plants. However, to date, there does not appear to be as much attention being paid to developing externalities-related values for biomass-based resources, or other renewables-oriented projects, as for fossil fuel-based resources.

Even if externalities considerations become more prevalent, it is not clear that renewables-based projects, particularly those utilizing biomass resources, would receive much of a benefit compared to high-efficiency, natural-gas-based generation. Particularly important in this regard is the treatment of offsets; biomass projects may have little, if any, externalities penalty if $\mathrm{CO}_{2}$, methane, and other emissions offsets are factored in.

A number of states and utilities are pursuing alternative approaches to assuring the proper valuation of renewable energy attributes in utility resource planning and acquisition. Among the approaches are the use of "green RFPs," utility incentives, and capacity set-asides for renewable energy projects. The relative value of pursuing these other approaches, either separate from or in combination with externalities valuations, should be assessed. 


\begin{tabular}{|c|c|c|c|c|c|c|}
\hline State & Monetization & $\begin{array}{c}\text { Percentage } \\
\text { Adder }\end{array}$ & Qualitative & Considering & $\begin{array}{c}\text { Considered but } \\
\text { No } \\
\text { Requirements }\end{array}$ & $\begin{array}{l}\text { Has Not } \\
\text { Addressed }\end{array}$ \\
\hline Alabama & & & & & & $\checkmark$ \\
\hline Alaska & & & & & 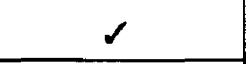 & \\
\hline Arizona & & & $s$ & & & \\
\hline Arkansas & & & $\checkmark$ & & & \\
\hline California & $\checkmark$ & & & & & \\
\hline Colorado & & & $\checkmark$ & & & \\
\hline Connecticut & & & 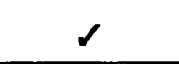 & & & \\
\hline Delaware & & & 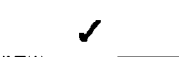 & & & \\
\hline District of Columbia & & & & $\checkmark$ & & \\
\hline Florida & & & & $\checkmark$ & & \\
\hline Georgia & & & 2 & & & \\
\hline Hawaii & & & $\checkmark$ & & & \\
\hline Idaho & & & $\checkmark$ & & & \\
\hline Illinois & & & $\checkmark$ & & & \\
\hline Indiana & & & & $\checkmark$ & & \\
\hline lowa & & 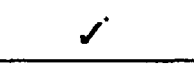 & & & & \\
\hline Kansas & & & & 2 & & \\
\hline Kentucky & & & & & & 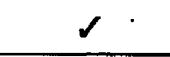 \\
\hline Louisiana & & & & & & $s$ \\
\hline Maine & & & & & $s$ & \\
\hline Maryland & & & & $\checkmark$ & & \\
\hline Massachusetts & $\checkmark$ & & & & & \\
\hline Michigan & & & 1 & & & \\
\hline Minnesota & & & 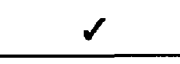 & & & \\
\hline Mississippi & & & & & & $s$ \\
\hline Missouri & & & $\checkmark$ & & & \\
\hline Montana & & & 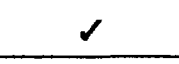 & & & \\
\hline Nebraska & & & & & & 2 \\
\hline Nevada & $\checkmark$ & & & & & \\
\hline New Hampshire & & & & & $\checkmark$ & \\
\hline
\end{tabular}




\begin{tabular}{|c|c|c|c|c|c|c|}
\hline State & Monetization & $\begin{array}{c}\text { Percentage } \\
\text { Adder }\end{array}$ & Qualitative & Considering & $\begin{array}{c}\text { Considered but } \\
\text { No } \\
\text { Requirements }\end{array}$ & $\begin{array}{c}\text { Has Not } \\
\text { Addressed }\end{array}$ \\
\hline New Jersey & & & $\checkmark$ & & & \\
\hline New Mexico & & & & $\checkmark$ & & \\
\hline New York & $\checkmark$ & & & & & \\
\hline North Carolina & & & & & $\checkmark$ & \\
\hline North Dakota & & & & & & $\checkmark$ \\
\hline Ohio & & & $\checkmark$ & & & \\
\hline Oklahoma & & & $\checkmark$ & & & \\
\hline Oregon & & & $\checkmark$ & & & \\
\hline Pennsylvania & & & $\checkmark$ & & & \\
\hline Rhode Island & & & & & $\checkmark$ & \\
\hline South Carolina & & & & & $\checkmark$ & \\
\hline South Dakota & & & & & & $\checkmark$ \\
\hline Tennessee & & & & & & $\checkmark$ \\
\hline Texas & & & $\checkmark$ & & & \\
\hline Utah & & & $\checkmark$ & & & \\
\hline Vermont & & $\checkmark$ & & & & \\
\hline Virginia & & & $\checkmark$ & & & \\
\hline Washington & & & $\checkmark$ & & & \\
\hline West Virginia & & & & & & $\checkmark$ \\
\hline Wisconsin & $r$ & & & & & \\
\hline Wyoming & & & & & & $\checkmark$ \\
\hline Totals & 5 & 2 & 22 & 6 & 6 & 10 \\
\hline
\end{tabular}

DSM-only and for the first $120 \mathrm{MW}$ of renewables acquired.

"Separate requirements for consideration of externalities in IRP, competitive bidding, and facility siting.

Sources: (Barakat \& Chamberlin 1993); (Cohen et al. 1990a); and National Renewable Energy Laboratory, personal communications with state utility commissions. 
Table 3-B. Representative Emissions Factors and Heat Rates for New Plants Utilized in Table 3-3 (Ib/MBtu," unless otherwise noted)

\begin{tabular}{|c|c|c|c|c|c|c|c|c|c|}
\hline Technology/Fuel & $\begin{array}{l}\text { Heat Rate } \\
\text { Btu/kWh }\end{array}$ & $\mathrm{NO}_{x}$ & $\mathrm{SO}_{\mathrm{x}}$ & $\mathrm{CO}_{2}$ & $\mathrm{CH}_{4}$ & $\mathrm{CO}$ & TSP & Voc & $\mathrm{N}_{2} \mathrm{O}$ \\
\hline $\begin{array}{l}\text { Pulverized Coal with } \\
\text { Scrubbers }\end{array}$ & 9,400 & 0.6 & 0.6 & 238 & 0.0015 & 0.024 & 0.03 & 0.004 & 0.0325 \\
\hline $\begin{array}{l}\text { Atmospheric Fluidized Bed } \\
\text { Coal }\end{array}$ & 10,000 & 0.18 & $\begin{array}{l}0.03^{*} \\
0.0066\end{array}$ & 238 & 0.0015 & 0.15 & 0.01 & 0.0028 & 0.0325 \\
\hline $\begin{array}{l}\text { Integrated Gasification } \\
\text { Combined Cycle Coal }\end{array}$ & 9,280 & 0.06 & $\begin{array}{l}0.03^{*} \\
0.0066\end{array}$ & 198 & 0.0015 & 0.01 & 0.006 & 0.003 & 0.0325 \\
\hline Natural Gas Combined Cycle & 8,140 & 0.0787 & 0.0006 & 117 & 0.002 & 0.021 & 0.001 & 0.033 & 0.0078 \\
\hline $\begin{array}{l}\text { Steam Injected Natural Gas } \\
\text { Combustion Turbine }\end{array}$ & 13,100 & 0.0787 & 0.0006 & 119 & 0.012 & 0.1095 & 0.0133 & 0.012 & 0.018 \\
\hline Wood & 16,740 & 0.03875 & 0.0083 & 212 & 0.033 & 0.221 & 0.00486 & 0.0773 & 0.033 \\
\hline BIG STIG & 10,500 & 0.06 & 0.008 & 212 & 0.0015 & 0.002 & 0.011 & 0.003 & 0.0325 \\
\hline Municipal Solid Waste & 16,800 & 0.077 & 0.038 & 165 & 0.0014 & 0.93 & 0.0047 & 0.03 & 0.033 \\
\hline $\begin{array}{l}\text { Flashed Steam Geothermal } \\
\text { w/Injection }\end{array}$ & 40,000 & NA & NA & 0.03 & 0.0001 & NA & NA & NA & NA \\
\hline $\begin{array}{l}\text { Parabolic Trough with } \\
\text { Natural Gas }\end{array}$ & 11,000 & 0.031 & 0.0006 & 119 & 0.0002 & 0.038 & 0.0029 & 0.0013 & 0.028 \\
\hline $\begin{array}{l}\text { Landfill Methane } \\
\text { (in } \mathrm{lb} / \mathrm{MWh} \text { ) }\end{array}$ & NA & 2.66 & 0.63 & 1375 & -500 & 6.66 & 0.00 & 0.74 & 0.00 \\
\hline
\end{tabular}

Multiply by $4.3 \times 10^{-7}$ to convert from $\mathrm{lb} / \mathrm{MBtu}$ to $\mathrm{kg} / \mathrm{kJ}$

"First value is for northern U.S.; second value is for western U.S.

Sources: $\quad$ Nevada Public Service Commission, In Re Rulemaking Regarding Resource Planning Changes Pursuant To SB 497, Order 89-752, January 22, 1991, Table 1, except as noted below.

$\mathrm{NO}_{x}, \mathrm{SO}_{x}$, and TSP emission factors for atmospheric fluidized bed coal and integrated gasification combined cycle goal estimated by NREL staff. Assumptions include $2.5 \%$ sulfur content for northern coal and $0.55 \%$ sulfur content for western coal, and $12 \%$ ash content.

$\mathrm{NO}_{x}$ data for pulverized coal estimated by NREL staff. Assumptions include control technologies for $65 \%$ $\mathrm{NO}_{x}$ reduction.

BIG STIG data, except for $\mathrm{CO}_{2}$ data, from Union of Concerned Scientists et al., America's Energy Choices (Technical Appendixes). Cambridge, MA: Union of Concerned Scientists, 1992. pp. H-6, l-4, and I-5. $\mathrm{CO}_{2}$ data estimated by NREL staff.

Landfill methane data provided by New England Power in testimony filed in support of "green RFP" initiative, August 1993. 
Additional notes and assumptions for Table 3-B:

- The atmospheric fluidized bed coal units are equipped with scrubbers for $95 \%$ sulphur dioxide removal, low $\mathrm{NO}_{x}$ burners, and ammonia injection for $65 \%$ removal of $\mathrm{NO}_{x}$.

- The integrated coal gasification units have $95 \% \mathrm{SO}_{2}$ removal and steam injection to remove $70 \%$ of $\mathrm{NO}_{x}$.

- The combined cycle units have steam/water injection to remove $80 \%$ of $\mathrm{NO}_{\mathrm{x}}$ and oxidation catalyst to reduce $80 \%$ of carbon monoxide.

- The combustion turbines have steam injection to remove $80 \%$ of $\mathrm{NO}_{x}$.

- The parabolic trough system has low $\mathrm{NO}_{\mathrm{x}}$ burners.

- Wood and MSW are equipped with fabric filter baghouses for $99 \%$ removal of particulates and $\mathrm{NO}_{x}$ controls for a $75 \%$ reduction of $\mathrm{NO}_{x}$. MSW units also have wet/dry scrubbers for $90 \%$ reduction of $\mathrm{SO}_{\mathrm{x}}$.

- The chart reflects emissions offsets for $\mathrm{CO}_{2}$ and $\mathrm{CH}_{4}$ that may be available for wood, BIG STIG, and landfill methane. The chart does not reflect offsets that may be available for other pollutants or technologies. For example, Massachusetts allows offsets for $\mathrm{SO}_{2}, \mathrm{NO}_{x}$, particulates, and VOCs; Wisconsin allows greenhouse gas offsets; and California allows $\mathrm{NO}_{x}$ offsets in its bidding process.

The BIG STIG data, except for $\mathrm{CO}_{2}$ and $\mathrm{SO}_{\mathrm{x}}$, are derived from estimates for coal-based IGCC technology (following the UCS study) and thus should be considered very preliminary. The $\mathrm{CO}_{2}$ and $\mathrm{SO}_{\mathrm{x}}$ values are from the Nevada PSC rulemaking. 


\section{Perceptions of Biomass Power Technologies}

\section{Introduction}

In previous sections, the characteristics of biomass resources and technologies and their associated externalities have been profiled, as well as trends among states in the consideration of these externalities in utility resource planning and procurement. Discussions were held with representatives of the biomass project development industry, electric utilities, and state regulatory agencies in order to gain additional insights into the potential impact that externalities consideration may have on future biomass development. This section reports on the findings from these discussions.

\section{Industry Contacts}

A representative group of biomass and utility industry participants were contacted by telephone to identify and discuss their perceptions of the most important issues facing biomass project development, including the potential impact of externalities consideration. Twelve development companies were selected from the biomass industry; four each from the wood waste, waste-toenergy (WTE), and landfill gas (LFG) industries. Sixteen representatives of the electric utility industry were contacted. The utility group was chosen to be geographically diverse and include both investor-owned and publicly owned utilities, as well as utilities with biomass development experience, either as plant operators or as power purchasers. Finally, 17 state regulatory agencies representing 11 different states were contacted, again to reflect both geographic diversity and states with either direct experience with biomass development or abundant biomass resources. The majority of the state contacts were with the utility regulatory agency, although some contacts were made with energy offices and planning and siting agencies.

\section{General Findings on Biomass}

Below we present a general summary of the project development experiences and perceptions gleaned from the industry discussions. The responses have been separated into the three categories of discussants: project developers, electric utilities, and state regulatory agencies.

\section{Biomass Project Developers}

The primary impetus to biomass project development has been the favorable power purchase contracts that developers have received under PURPA, although WTE plants have more often been pursued by municipalities as a response to community waste disposal needs. The main selling point for many biomass projects has been the reputation and experience of the developer.

Many project developers noted that environmental and siting concerns (e.g., the not-in-my backyard or NIMBY syndrome) are the primary issues that contribute to public opposition to biomass projects. Air quality concerns have been paramount, particularly when projects are located close to urban areas. Secondary concerns arise over ash disposal and the impact of fuel transport on local traffic. Remotely located plants have elicited less opposition. The permitting 
process for biomass projects varies significantly but has become more difficult over time. Air permits are generally the most difficult to obtain.

At the same time, many developers noted that environmental benefits are the primary factor that have contributed to public support of biomass projects. These include the waste disposal benefits of wood waste combustion and the landfill reduction benefits of WTE projects. In addition, it was noted that the public perception of biomass plants generally improves after these plants commence operation.

It was generally felt that explicit consideration of externalities would benefit biomass power plants. However, there was a perception that WTE plants would benefit less, if at all, than other types of biomass because of other WTE-specific issues.

\section{Electric Utilities}

The utility evaluation process for biomass varies widely. It tends to involve first a resource assessment and then an economic evaluation. Generally, biomass ranks in the middle to lower third of utility resource options, lower than demand-side management (DSM), natural gas (in a combined cycle configuration), and coal. However, one representative noted that wood waste represents the most cost-effective longer term resource addition for that utility. Another mentioned that biomass will soon represent $30 \%$ of total system capacity. In a few cases, biomass is given credit as a renewable resource. Some respondents noted that excess capacity and the current emphasis on DSM reduces the likelihood that their utility would pursue biomass development in the near future.

Many benefits were ascribed to biomass technologies, such as local economic development and job creation, especially in rural areas; waste disposal and volume reduction of MSW; the renewable nature of the resources; the use of local fuel resources versus imported fuel; the potential for greenhouse gas mitigation; and other emissions reductions and credits. However, a number of disadvantages were also mentioned, including: facility emissions; the cost of fuel delivery and handling; variability in fuel properties; and the inability of these plants to follow load.

Some of the utilities contacted consider externalities in resource decisions, but the methods differ. Other utilities do not measure externalities directly but do consider environmental costs in resource modeling scenarios and sensitivity analyses, or as a nonprice factor in competitive bidding evaluations. Other utilities expect that they will be required to consider externalities in the future.

The utility perception of the possible impacts of externalities consideration on biomass development was mixed. Some utilities view explicit consideration of externalities as positive for biomass, while others saw it as a negative or were uncertain. It was noted that the treatment of $\mathrm{CO}_{2}$ emissions would have an important impact on the externalities ranking of different types of biomass. $\mathrm{NO}_{\mathrm{x}}$ emissions are also a concern in some regions such as the Northeast and Southern California. 
The general utility experience with nonutility biomass projects has been positive, although there is concern over the high prices that some nonutility developers (of all types) receive for their power output under PURPA. At least one utility indicated that it is seeking to renegotiate contracts with nonutility developers, including biomass developers. Responses varied on the relative ease of biomass plant siting and permitting; there was a general consensus that natural gas projects are the least difficult to site. However, all types of biomass projects are considered to be easier to site than coal-based projects.

There was a wide diversity of opinion on the biggest issues and challenges facing biomass in the future. Those mentioned more than once were the need to lower biomass power costs, the lower cost of competing fuels, siting, and the incompatibility of biomass power for meeting peaking power needs.

\section{State Regulators}

State regulators, in general, are most concerned with economic issues, noting that, over the near term, economic issues will impact biomass technologies more than environmental issues. Some states have capacity surpluses, and thus utilities are not evaluating new supply options of any kind. In these states, overcapacity is keeping avoided costs low, discouraging any new plant development.

It was noted that few utilities evaluate biomass in their resource plans, and that some utilities appear to have conceded biomass development to nonutility developers. However, in some states, utilities have been reluctant to negotiate contracts or pay capacity payments to nonutility developers, including biomass, and litigation is pending in at least two states involving complaints by nonutility developers, biomass, and nonbiomass alike.

Many early nonutility projects, including biomass projects, received contracts with high avoided cost rates. These contracts have forced utilities to seek rate increases, which has contributed to public opposition to some plants. Regulators and the public are now more sensitive to the economics of biomass plants.

State approval over power plant development can be spread over several regulatory agencies. It was felt in several states that the communication and coordination between these agencies could be improved. Few of the state representatives contacted had much involvement in facility siting and thus could not readily compare the ease or difficulty of siting a biomass facility to a fossil fuel plant. Some respondents felt that wood waste and LFG plants would be easier to site than coal plants, but would be roughly the same as a natural gas plant. WTE plants were considered difficult to site in general because of public opposition, except perhaps in pre-existing industrial zones.

It is generally felt among regulators that environmental externalities will benefit wood waste and landfill gas but perhaps not enough to overcome the perceived environmental advantages of other resource options, such as natural gas, wind, and geothermal technologies. Some respondents cautioned that any externalities benefits will depend on the degree to which biomass combustion can be considered $\mathrm{CO}_{2}$-neutral. Many thought that externalities consideration would have a negative impact on WTE projects. 
Several regulators noted that biomass development would receive a boost if economic factors, such as job creation, were considered along with environmental externalities. And finally, in states with excess capacity, it was felt that externalities, if evaluated at all, would not have any impact on biomass until new capacity resources are needed.

\section{Fuel-Specific Findings}

As noted in previous sections of this report, the characteristics of biomass energy resources and power generation technologies are quite varied. Thus, the perceptions of these resources will also vary. The following represents fuel-specific perceptions of biomass energy resources and technologies. The bulk of these comments come from the biomass project developers since the discussions with developers tended to be more technology specific.

\section{Wood Waste}

\section{Project Developers}

Many wood waste projects have been developed because of PURPA and the favorable power sales contracts that it spawned and plentiful supplies of wood waste. Wood waste also provided a niche market for many developers. The main selling points for wood waste projects have been favorable environmental considerations and the good reputation of the development companies.

Generally, public perception of wood waste projects has not changed over time. Positive issues that have contributed to public support for projects include environmental benefits and the renewable nature of the resource. Other responses included the fact that wood is a domestic resource, waste disposal benefits, new industrial infrastructure development in the community, and the more moderate size of these facilities. Negative issues include environmental concerns and general public opposition to the projects, e.g., NIMBY sentiments.

The developers noted that wood waste technology has been treated well in the permitting process, although this can vary by location. For example, developers noted that it is more difficult to site projects in the Northeast. However, today's wood waste projects are subjected to more stringent permitting requirements than in the past. Water permits are generally the easiest permits to obtain while air permits are the most difficult. Wood waste power plants are considered easier to permit than coal but roughly comparable to natural gas plants.

The impact of state utility regulatory processes on the development of wood waste plants varies from state to state, both positive and negative. For example, state implementation of PURPA was a positive in the $1980 \mathrm{~s}$, but the advent of competitive bidding for new resource procurement is a negative. The project developers feel that explicit consideration of externalities in electric utility planning and procurement practices will benefit wood waste projects in the future.

A number of issues and challenges currently confront wood waste project development. Issues mentioned by developers were the need to account for externalities in energy prices, overcoming community resistance to project construction, lower avoided costs, more stringent particulate and $\mathrm{NO}_{\mathrm{x}}$ controls, and the need to disassociate wood ash disposal issues from MSW ash. 


\section{Electric Utilities}

Electric utility respondents indicated that there has been both support and opposition to wood and wood waste plants. However, several utilities considered wood plants to be easier to site than coal plants, particularly if the plants are located in economically depressed areas. Regarding environmental externalities, future issues for wood-based projects include $\mathrm{CO}_{2}$ emissions and $\mathrm{NO}_{x}$ compliance. It was questioned whether any environmental externalities benefits for biomass would be great enough to overcome the current price advantage versus natural gas.

\section{State Regulators}

The state contacts felt that wood waste plants are comparatively easy to site, but can face public opposition based on any number of factors, such as air emissions, land use, impacts on endangered species, fears of overharvesting forest resources, and site-specific impacts such as plant noise and traffic from fuel delivery trucks. In cases where wood waste plants are sited near traditional forest product or paper mills or in economically depressed areas, they are more readily accepted.

The impact of externalities on wood waste will depend on the treatment of $\mathrm{CO}_{2}$ emissions. The market potential for wood waste projects will be severely hampered if a $\mathrm{CO}_{2}$ adder is applied to wood waste. If wood combustion is considered to be $\mathrm{CO}_{2}$-neutral, wood waste would probably be more environmentally and economically competitive than coal, but still not as competitive as natural gas.

\section{Waste-to-Energy}

\section{Project Developers}

Waste-to-energy projects have generally been developed by private entities on behalf of municipal governments or entities. The main selling points for WTE projects have been the track record of the technology and the developer.

The following positive issues were noted as having contributed to past public support of WTE plants: the benefits of waste combustion and energy recovery versus landfilling, cost, the reputation of the company, environmental benefits, and provision of a stable long-term disposal solution. Negatives identified were: air pollution concerns; perceived loss of property values; ash disposal; incompatibility with recycling; energy costs; general public opposition; and traffic congestion.

The permitting of WTE projects varies from state to state, but these projects are generally scrutinized in great detail. Permitting standards have increased as both WTE technology and emissions monitoring has improved. In some cases, air permits were cited as the most difficult to obtain; in one case, it was a local "conditional use" permit. Permits for disposal of the remaining solid waste can sometimes prove difficult to obtain. WTE plants were compared to coal-fired power plants in permitting complexity, while natural gas plants were said to be easier to permit. 
It was noted by developers that regulators appear to be comfortable with WTE technology but that public understanding lags. Public perception generally changes for the better once a project has been built and is operating.

Explicit consideration of externalities was felt to be less of an issue for WTE projects than for other resource options because waste disposal needs are what initially drive the development of WTE facilities; electricity economics are a secondary concern. However, it was felt that a favorable accounting of externalities might make certain projects more feasible.

There are many issues and challenges confronting the future development of WTE projects, including compatibility with recycling; overcoming negative public perceptions, including developing a better public understanding of WTE air quality controls; and siting.

\section{Electric Utilities}

The utility representatives view WTE plants as the most difficult type of biomass plant to site because of the widespread public opposition that has developed. One utility representative, however, expressed support for WTE as a component of a total waste disposal strategy encompassing recycling, source reduction, and composting. Under such a scenario, WTE plants would be smaller in scale and utilize a more uniform fuel. It was also noted that WTE plants are base load, must run power sources that are not highly valued today from a utility operations standpoint.

\section{State Regulators}

State regulators generally view MSW as a problematic resource option; they note that WTE plants are becoming increasingly difficult to site unless they are located in heavily industrialized areas. WTE plants also are viewed as an expensive energy option and a logistical problem if the waste fuel must be brought in from outside the community. In some states, aggressive recycling and source reduction efforts have put a damper on the development of WTE plants. Yet, one state regulator predicted a bright future for WTE within the state because of the combination of a rapidly growing urban population, a relatively undeveloped recycling effort, and a lack of landfill sites.

Several regulators noted that WTE plants have had a mixed performance record, with some plants exceeding expectations but others marred by unanticipated shutdowns and/or excessive air emissions.

Some state respondents thought that WTE plants would not fare as well as wood waste or landfill gas plants when externalities are considered; concerns over emissions and ash disposal may be considered negative externalities for WTE projects. 


\section{Landfill Gas}

\section{Project Developers}

Like other biomass power projects, many LFG projects have been developed primarily because of PURPA and favorable power sales contracts. In addition, LFG production benefits from the federal unconventional fuels tax credit. In one case, an LFG project was developed for its public relations value. The main selling points for past LFG projects have been economic feasibility and environmental benefits.

The principal positive issue that has contributed to public support of LFG plants is the beneficial use or reduction of migrating landfill gas as well as reduced odor. Negative issues have included noise, NIMBY concerns, and architectural review issues. Most developers felt that landfill gas is treated fairly in the permitting process but receives no special consideration. Generally, public perception toward LFG plants is positive and in some cases has changed for the better.

The easiest permits for LFG plants to obtain are building permits; air permits are the most difficult. In general, all of the permitting for LFG projects has become more difficult, and the need for more sophisticated emissions control technologies has increased costs. However, because LFG projects tend to be small, the permitting process is easier than for larger fossil fuel generating plants.

The primary impact of the state utility regulatory process on landfill gas projects has been the availability of power sales contracts. The developers all agreed that the explicit consideration of externalities would be beneficial for LFG projects.

Future challenges or issues for LFG projects include new environmental regulations, a more competitive marketplace for power, and obtaining additional economic incentives.

\section{Electric Utilities}

There were very few comments by utilities regarding LFG projects. Generally, it was felt that there has been little public opposition to LFG plants and that these plants are relatively easy to site. One utility representative noted that the state is encouraging LFG projects to generate revenue for closed landfills and to mitigate methane emissions. In addition, this representative stated that utility management supports LFG project development as a component of its greenhouse gas reduction strategy. However, it also was noted that LFG power projects may require $\mathrm{NO}_{\mathrm{x}}$ offsets if located in nonattainment areas.

\section{State Regulators}

Landfill gas plants will benefit from externalities because they reduce methane leakage from landfills (methane is considered to be a more potent greenhouse gas than $\mathrm{CO}_{2}$ ), and because they utilize a pre-existing waste resource. However, in some areas, $\mathrm{NO}_{\mathrm{x}}$ emissions from combustion could be a problem. LFG plants are considered to be easy to site because of the perception that plants mitigate potential environmental problems and, in most instances, are sited in remote or otherwise unattractive landfill locations. 


\section{Conclusions}

The following represents a summary of our discussions with representatives of the biomass project development industry, the electric utility industry, and state regulatory agencies:

- Much of the biomass development that has occurred to date resulted from the response of nonutility developers to the incentives that were created by PURPA. The high-priced payment contracts of the past are no longer available and, with lower utility avoided costs, the power generation market has become much more competitive.

- Only a handful of electric utilities have direct experience in developing biomass power projects because the majority of this development has been performed by nonutility generators. State utility regulators also appear to have paid less attention to the relative benefits of biomass development compared to traditional fossil-fuel-based generation. The focus of most state regulators is on traditional project economics.

- The public perception of biomass development varies widely. The environmental characteristics of biomass projects were cited as both potential positives and -negatives. In general, the permitting requirements for all types of biomass projects have become more stringent.

- The potential impact of externalities consideration on future biomass development is unclear. Generally, biomass externalities are considered to be more favorable than coal but less favorable than natural gas or other renewables-based resource options. For woodfired projects, the treatment of $\mathrm{CO}_{2}$ emissions (i.e., whether or not wood-fired plants receive $\mathrm{CO}_{2}$ offsets) will be an important factor. LFG projects may benefit from methane reduction considerations. 


\section{References}

Anderson, C. (1992). Testimony before the Wisconsin Public Service Commission. Docket No. 05-EP-6. December 3.

Bain, R.; Overend R. (1992). "Biomass Electric Technologies: Status and Future Development." Advances in Solar Energy: An Annual Review of Research and Development. Boulder, CO: American Solar Energy Society, K. Boer ed., Volume 7.

Barakat \& Chamberlin Inc. (1993). Contents of EPRINET's Environmental Externalities Clearinghouse: State Regulatory News. June.

Berenyi, E.; Gould, R. (1991). 1991-1992 Methane Recovery from Landfill Yearbook. New York: Governmental Advisory Associates Inc.

Berenyi, E.; Gould, R. (1993). 1993 Resource Recovery Yearbook. New York: Governmental Advisory Associates Inc.

Bernow, S.; Biewald, B.; Marron, D. (1991). "Full-Cost Dispatch: Incorporating Environmental Externalities in Electric System Operation." The Electricity Journal. March.

Biewald, B.; Bernow, S. (1992). "Climate Change and the U.S. Electric Sector." Proceedings: Fourth National Conference on Integrated Resource Planning Washington, DC: National Association of Regulatory Utility Commissioners.

Boston Edison Co. (1992). RFP 3 - Final Public Summary. June 1.

Broom, R; Stasis, R; Williams, J. (1993). "Waiting for the Other Shoe to Drop: New Air Quality Rules for WTE." Solid Waste \& Power. May/June.

Brower, M; Tennis, M; Denzler, E.; Kaplan, M. (1993). Powering the Midwest: Renewable Electricity for the Economy and the Environment. Cambridge, MA: Union of Concerned Scientists.

Browne, G. (1991a). "A Utility View of Externalities: Evolution, Not Revolution." The Electricity Journal. March.

Browne, G. (1991b). "Environmental Dispatch." Proceedings from the Conference on DemandSide Management and the Global Environment. Palo Alto, CA: Electric Power Research Institute. April.

Buchanan, S. (1990). "Estimating Environmental Costs of Energy Resources." The Electricity Journal. July. 
Buchanan, S. (1992). "Dancing with the Bear: Lessons Learned in Applying Externality Costs to Real World Resources." Proceedings: Fourth National Conference on Integrated Resource Planning. Washington, DC: National Association of Regulatory Utility Commissioners.

California Public Utilities Commission. (1991). Order Instituting Investigation on the Commission's own motion to implement the Biennial Resource Plan Update following the California Energy Commission's Seventh Electricity Report. "Phase 1B Opinion: Changes to Final Standard Offer 4 for Use in Conjunction with the 1990 Electricity Report." Decision 9106-022. June 5.

California Public Utilities Commission. (1992). Interim Opinion, Resource Plan Phase: Bidding for New Generation Sources. Decision 92-04-045. April 22.

Charles, M. (1992). "Integrated Waste Management-If It's Not Broke, Why Fix It?" Waste Age. November.

Chupka, M.; Howarth, D; Zoi, C. (1992). Renewable Electric Generation: An Assessment of Air Pollution Prevention Potential. Washington DC: U.S. Environmental Protection Agency. ANR445. March.

Clinton, W.; Gore, A. (1993). Climate Change Action Plan. October.

Cohen, S.; Eto, J.; Goldman C.; Beldock J.; Crandall G. (1990a). A Survey of State PUC Activities to Incorporate Environmental Externalities into Electric Utility Planning and Regulation. Berkeley, CA: Lawrence Berkeley Laboratory, LBL-28616. May.

Cohen, S.; Eto, J.; Goldman C.; Beldock J.; Crandall G. (1990b). "Environmental Externalities: What State Regulators Are Doing." The Electricity Journal. July.

Connecticut Office of Policy and Management. (1990). Study of the Potential Impact and Benefit of Wood Burning Facilities in Connecticut. January.

Doll, D. (1993). Personal Communication. Research Triangle Park, NC: U.S. Environmental Protection Agency. June 10.

Eco Northwest; Shapiro and Associates; Seton, Johnston and Odell. (1986). Estimating Environmental Costs and Benefits for Five Generating Resources. Portland, OR: Bonneville Power Administration. March.

Edison Electric Institute. (1993). 1992 Capacity and Generation of Non-Utility Sources of Energy. Washington, D.C.

Electric Utility Week. (1992). "PG\&E Anticipates Losing Numerous Wood Units Selling Power to Grid." Electric Utility Week. February 24.

Feher, J. (1984). "A Comparison of Siting Factors for Various Electricity-Generating Technologies." Proceedings of the 19th Intersociety Energy Conversion Engineering Conference. 
Fehrs, J.; Donovan, C. (1993). "Environmental Issues: New Techniques for Managing and Using Wood Ash." Proceedings: First Biomass Conference of the Americas. Volume I. Golden, CO: National Renewable Energy Laboratory.

Freeman, A.; Burtraw D.; Harrington W.; Krupnick A. (1992). "Externalities - How to Do it Right." The Electricity Journal. August/September.

Gaige, C.; Halil, R. (1992). "Clearing the Air About Municipal Waste Combustors." Solid Waste \& Power. January/February.

Gold, B.; Tillman, D. (1993). "Wood Cofiring Evaluation at TVA Power Plants: EPRI Project RP 3704-1." Presented at the Conference on Strategic Benefits of Biomass and Waste Fuels. Washington, D.C.: Electric Power Research Institute. March 28 - April 1.

Hachey, M. (1993). "New England Power Company's Renewable Energy Initiative (Green RFP)." Proceedings of the National Regulatory Conference on Renewable Energy. Washington, DC: National Association of Regulatory Utility Commissioners. October.

HCI Publications. (1993). Landfill Gas-to-Energy: 1993 Activity Report. Kansas City, MO.

Henderson, T. (1992). Personal Communication. Nevada Public Service Commission. August.

Hoffman, W.; Cook, J.; Beyea J. (1993). "Some Ecological Guidelines for Large-Scale Biomass Plantations." Proceedings: First Biomass Conference of the Americas. Volume I. Golden, CO: National Renewable Energy Laboratory.

Hollenbacher, R. (1992). "Biomass Combustion Technologies in the United States." Paper presented at the Biomass Combustion Conference, Reno, NV, January 28-30.

Hougan, O. et al. (1943). Chemical Process Principles. Part 1, Material and Energy Balances. New York: John Wiley \& Sons, Inc., Second Edition.

Hughes, M.; Ranney, J. (1993). "Environmental Issues Related to Biomass: An Overview." Proceedings: First Biomass Conference of the Americas. Volume I. Golden, CO: National Renewable Energy Laboratory.

Iliff, D. (1993). Personal Communication. Wisconsin Public Service Commission. August 12. Independent Power Report. (1993). "Supreme Court Agrees to Hear Appeal of Chicago Case on Incinerator Ash." Independent Power Report. July 2.

Joskow, P. (1992). "Weighing Environmental Externalities: Let's Do It Right!" The Electricity Journal. May.

Kiser, J. (1992a). "Municipal Waste Combustion Ash: Recent Developments." Environmental \& Waste Management World. Vol. 6, No. 5. May. 
Kiser, J. (1992b). "Municipal Waste Combustion in North America: 1992 Update." Waste Age. November.

Kiser, J. (1993). "Putting the Pieces Together: Integrated Waste Management." American City \& County. June.

Klass, D. (1983). "Energy and Synthetic Fuels from Biomass and Wastes." Handbook of Energy Technology and Economics. New York: John Wiley \& Sons, R. Meyers ed., pp. 712-786.

Levin, M; Smith, (1991). "New Landfill Gas Emission Rules Present Problems, Opportunities." Solid Waste \& Power. December.

Lusk. P. (1993). Personal Communication. May 17.

McCarroll R.; Partanen, W. (1993). "On-Site Power Generation for the Future." Proceedings: First Biomass Conference of the Americas. Volume I. Golden, CO: National Renewable Energy Laboratory.

McGowin C.; Gold, B. (1992). "Potential Benefits of Co-Firing Wood and Coal." Presented at the 5th Annual National Biofuels Conference. Newton, MA. October.

Massachusetts Department of Public Utilities. (1990). Investigation by the Department of Public Utilities on its own motion into proposed rules to implement integrated resource management practices for electric companies in the Commonwealth. D.P.U. 89-239. August 31.

Massachusetts Department of Public Utilities. (1991). Investigation by the Department on its own motion into the filing made by Eastern Edison Company pursuant to 220 C.M.R. 8.00, rules governing sales of electricity by small power producers and cogenerators to utilities and sales of electricity by utilities to small power producers and cogenerators. D.P.U. 90-141. June 14.

Massachusetts Department of Public Utilities. (1992). Investigation by the Department of Public Utilities on its own motion as to the environmental externality values to be used in resource costeffectiveness tests by electric companies subject to the Department's jurisdiction. D.P.U. 91-131. November 10.

Midwest Research Institute. (1988). Guidelines for Co-firing Refuse-Derived Fuel in Electric Utility Boilers. Palo Alto, CA: Electric Power Research Institute, Volume 1: Executive Summary.

Minnesota, State of. (1993). An Act: . . providing that the public utilities commission establish a preference for renewable resource energy production . . . Chapter No. 356, H.F. No. 1253.

Morris, G. (1991). The California Biomass Energy Industry in 1990: Supply, Demand, and Outlook for Biomass Fuels. A Report to the Pacific Gas and Electric Company. Berkeley, CA: Future Resources Associates. May. 
Musso, J. (1991). Testimony before the Wisconsin Public Service Commission. Docket No. 05EP-6. December 3.

National Renewable Energy Laboratory (1993). Profiles in Renewable Energy: Case Studies of Successful Utility-Sector Projects. Golden, CO: National Renewable Energy Laboratory. DOE/CH10093-206. October.

Nevada Public Service Commission. (1991). Order. In Re rulemaking regarding resource planning changes pursuant to SB 497 . February 1.

New England Power Company. (1991). "Notice of Intent: Small Power Producer Request for Proposals."

New York Department of Public Service. (1989). "Consideration of Environmental Externalities in Competitive Bidding Program of Orange and Rockland Utilities."

New York Public Service Commission. (1992). Case 92-E-0954: Proceeding on Motion of the Commission to Examine the Plans for Implementation of Renewable Resources as Part of Meeting Future Electricity Needs in New York State. Order Instituting Proceedings. October 14.

New York Public Service Commission. (1993). Case 92-E-0954: Proceeding on Motion of the Commission to Examine the Plans for Implementation of Renewable Resources as Part of Meeting Future Electricity Needs in New York State. Settlement Agreement. October 12.

New York State Energy Office; Department of Public Service; Department of Environmental Conservation. (1991). Draft New York State Energy Plan: 1991 Biennial Update. Volume III: Issue Reports (Competitive Bidding). July.

Nicholson, R. (1978) Microeconomic Theory: Basic Principles and Extensions. Hinsdale, IL: The Dryden Press. Second Edition.

Office of Technology Assessment. (1980). Energy From Biological Processes. Washington, DC: U.S. Government Printing Office, Volume II - Technical and Environmental Analyses, p. 124.

Oregon Public Utility Commission. (1993) In the Matter of the Development of Guidelines for the Treatment of External Environmental Costs. Order No. 93-695. May 17.

Ottinger, R; et al. (1990). Environmental Costs of Electricity. New York: Oceana Publications.

Peterson, J. (1991). Wood Energy Technology Assessment. Albany, NY: New York State Energy Research and Development Authority. July.

Portland General Electric. (1993a). Request for Power Supply Proposals: Renewable Resource Technologies. June.

Portland General Electric. (1993b). Press Release. December 28. 
Project Finance Monthly. (1993). "IRS Adjusts Section 29 Tax Credit." Project Finance Monthly. April.

Putta, S. (1993). Personal Communication. New York Public Service Commission. August 10.

Rader, N.; Bossong K.; Becker, J.; Borson, D.; Manuel, C. (1990). The Power of the States: A Fifty-State Survey of Renewable Energy. Washington, D.C.: Public Citizen. June.

Research Triangle Institute. (1991). Biomass State-of-the-Art Assessment. Palo Alto, CA: Electric Power Research Institute, Volume 1: Guide.

Richards, D; et al. (1990). Waste-to-Energy Commercial Facilities Profiles. Park Ridge, NJ: Noyes Data Corporation.

Rinebolt, D. (1990). "Wood Power for the Future," Public Power, June.

Roos, K.; Jacobs, C.; Orlic, M. (1993). "Options for Cost-Effectively Reducing Atmospheric Methane Concentrations from Anthropogenic Biomass Sources." Proceedings: First Biomass Conference of the Americas. Volume III. Golden, CO: National Renewable Energy Laboratory.

Safley, L.; Lusk, P. (undated). "Low Temperature Anaerobic Digester." North Carolina Department of Economic and Community Development: Energy Division.

Sanghi, A. (1991). "Should Economic Impacts Be Treated as Externalities?" The Electricity Journal. March.

Solid Waste \& Power. (1991a). "New Jersey Advances First Regional Facility Since WTE Ban Lifted." Solid Waste \& Power. June.

Solid Waste \& Power. (1991b). "EPA Proposes Rules for Controlling Landfill Emissions." Solid Waste \& Power. August.

Solid Waste \& Power. (1991c). "EPA Issues Landfill Regulations," Solid Waste \& Power. December.

Solid Waste \& Power. (1992a). "Regulatory Requirements." Solid Waste \& Power. January/February.

Solid Waste \& Power. (1992b). "States Dismiss, Consider WTE Moratoriums." Solid Waste \& Power. May/June.

Solid Waste \& Power. (1992c). "Groups Seek Changes in Proposed Landfill Gas Rules," Solid Waste \& Power. 1992 Industry Sourcebook.

Solid Waste \& Power. (1993a). "Chicago Asks Supreme Court to Decide Ash Issue, Again." Solid Waste \& Power. May/June. 
Solid Waste \& Power. (1993b). "EPA Modifies Proposal for MSW Landfills." Solid Waste \& Power. November/December.

SRI International. (1992). Data Summary of Municipal Solid Waste Management Alternatives: Volume IV, Appendix B-RDF Technologies. Golden CO: National Renewable Energy Laboratory. NREL/TP-431-4988D. October.

Sutley, N; Works, D. (1992). Managing Externalities: Market Challenges and Solutions. Washington, DC: National Independent Energy Producers. October.

Sweet, J. (1991). Testimony before the Wisconsin Public Service Commission. Docket No. 05EP-6. December 3.

Swezey, B. (1993). The Impact of Competitive Bidding on the Market Prospects for Renewable Electric Technologies. Golden, CO: National Renewable Energy Laboratory. NREL/TP-4625479. September.

Talbot, T. (1991). Testimony before the Wisconsin Public Service Commission. Docket No. 05EP-6. December 3.

Taxation, Budget and Accounting. (1993). "IRS Issues Non-Conventional Source Fuel Credit, Inflation Credit, 1992 Price." Taxation, Budget and Accounting. April.

Taylor, H. (1990). "Municipal Waste-To-Energy Facilities Reduce Greenhouse Gas Emissions." (Black \& Veatch, Engineers-Architects). Presented at the Institute of Gas Technology Fourth Annual National Symposium on Municipal Solid Waste Disposal and Energy Production. January.

Tennessee Valley Authority. (1990). Economic Impact of Industrial Wood Energy Use in the Southeast Region of the U.S., Summary Report. Natural Fertilizer and Environmental Research Center, Biotechnical Research Department. TVA/NFERC/BIO-90/5 V.1, November.

Thorneloe, S. (1992). "Landfill Gas Utilization - Options, Benefits and Barriers." (U.S. Environmental Protection Agency) Presented at the Second United States Conference on Municipal Solid Waste Management. Arlington, VA. June 3-5.

Tillman, D.; Hughes, E.; Gold, B. (1993). "Cofiring of Biofuels in Coal Fired Boilers: Results of Case Study Analysis." Proceedings: First Biomass Conference of the Americas. Volume I. Golden, CO: National Renewable Energy Laboratory.

Turnbull, J.; Hay, G.; Hollenbacher, R. (1991). PG\&E Biomass Qualifying Facilities Lessons Learned Scoping Study - Phase I. San Ramon, CA: Pacific Gas and Electric Company. May.

U.S. Department of Energy. (1992). Electricity From Biomass: A Development Strategy. Office of Solar Energy Conversion, Solar Thermal and Biomass Power Division. April. 
U.S. Department of Energy. (1993a). Electricity from Biomass: National Biomass Power Program Five Year Plan (FY 1994-FY 1998). Office of Solar Energy Conversion, Solar Thermal and Biomass Power Division. April.

U.S. Department of Energy. (1993b). Annual Energy Review 1992. Washington D.C.: U.S. Government Printing Office. June.

U.S. Environmental Protection Agency. (1991) Standards of Performance for New Stationary Sources and Guidelines for Control of Existing Sources: Municipal Solid Waste Landfills. Federal Register. Vol. 56, No. 104. 40 CFR, Parts 51, 52 and 60. May 30.

U.S. House of Representatives. (1990) Compilation of Selected Acts - Environmental Law, as amended through December 31, 1990. Committee on Energy and Commerce. 102nd Congress, lst Session.

Vermont Public Service Board. (1990). "Investigation into Least-Cost Investments, Energy Efficiency, Conservation and Management of Demand for Energy." Order, Docket No. 5270, Volume IV. April 16.

Walther, R.; Jurewitz, J. (1992). "Including Environmental Externalities and Market-Based Mechanisms in Utility Resource Planning: Some Thoughts and Experiences." Advanced Workshop in Regulation and Public Utility Economics. San Diego: Fifth Annual Western Conference. July 8-10.

Wiel, S. (1991). "The New Environmental Accounting: A Status Report." The Electricity Journal. November.

Williams, S.; Porter, K. (1989). Power Plays: Profiles of America's Independent Renewable Electricity Developers. 1989 Edition. Washington, D.C.: Investor Responsibility Research Center.

Williams, S. (1991). Trash to Cash. Washington D.C.: Investor Responsibility Research Center.

Wiltsee, G.; McGowin, C.; Hughes, E. (1993). "Biomass Combustion Technologies for Power Generation." Proceedings: First Biomass Conference of the Americas. Volume I. Golden, CO: National Renewable Energy Laboratory.

Wisconsin Public Service Commission. (1992). Findings of Fact, Conclusion of Law and Order. Docket No. 05-EP-06. September 18.

Wisconsin Public Service Commission. (1993). Supplemental Findings of Fact, Conclusion of Law and Order, Supply Side, Renewable Technologies. Docket No. 05-EP-6. May 21. 


\begin{tabular}{|c|c|c|c|}
\hline $\begin{array}{l}\text { Document Control } \\
\text { Page }\end{array}$ & $\begin{array}{l}\text { 1. NREL Report No. } \\
\text { NREL-TP-462-5789 }\end{array}$ & $\begin{array}{l}\text { 2. NTIS Accession No. } \\
\text { DE94000247 }\end{array}$ & 3. Recipient's Accession No. \\
\hline \multirow{2}{*}{\multicolumn{3}{|c|}{$\begin{array}{l}\text { 4. Title and Subtitle } \\
\text { The Potential Impact of Externalities Considerations on the Market for } \\
\text { Biomass Power Technologies }\end{array}$}} & $\begin{array}{l}\text { 5. Publication Date } \\
\text { February } 1994 \\
\end{array}$ \\
\hline & & & 6. \\
\hline \multicolumn{3}{|c|}{$\begin{array}{l}\text { 7. Author(s) } \\
\text { B.G. Swezey, K.L. Porter, and J.S. Feher }\end{array}$} & 8. Performing Organization Rept. No. \\
\hline \multirow{2}{*}{\multicolumn{3}{|c|}{$\begin{array}{l}\text { 9. Performing Organization Name and Address } \\
\text { National Renewable Energy Laboratory } \\
1617 \text { Cole Boulevard } \\
\text { Golden, Colorado } 80401-3393\end{array}$}} & $\begin{array}{l}\text { 10. Project/Task/Work Unit No. } \\
\text { BF165155 and BF261011 }\end{array}$ \\
\hline & & & $\begin{array}{l}\text { 11. Contract (C) or Grant (G) No. } \\
\text { (C) } \\
\text { (G) }\end{array}$ \\
\hline \multirow{2}{*}{\multicolumn{3}{|c|}{ 12. Sponsoring Organization Name and Address }} & $\begin{array}{l}\text { 13. Type of Report \& Period Covered } \\
\text { Technical report }\end{array}$ \\
\hline & & & 14. \\
\hline \multicolumn{4}{|c|}{ 15. Supplementary Notes } \\
\hline \multicolumn{4}{|c|}{$\begin{array}{l}\text { 16. Abstract (Limit: } 200 \text { words) } \\
\text { This study assesses the current status of externalities considerations-nonmarket costs and benefits-in state and } \\
\text { utility electricity resource planning processes and determines how externalities considerations might help or hinder } \\
\text { the development of biomass power plants. It provides an overview of biomass resources and technologies, } \\
\text { including their market status and environmental impacts; reviews the current treatment of externalities in the } \\
\text { states; and documents the perspectives of key utility, regulatory, and industry representatives concerning } \\
\text { externalities considerations. The authors make the following recommendations to the biomass industry: (1) the } \\
\text { wood and agricultural waste industries should work toward having states and utilities recognize that wood and } \\
\text { agricultural waste are greenhouse gas neutral resources because of carbon sequestration during growth; (2) the } \\
\text { biomass industry should emphasize nonenvironmental benefits such as economic development and job creation; } \\
\text { and (3) the biomass industry should pursue and support efforts to establish renewable energy set-asides or "green" } \\
\text { requests for proposals. }\end{array}$} \\
\hline \multirow{2}{*}{\multicolumn{4}{|c|}{$\begin{array}{l}\text { 17. Document Analysis } \\
\text { a. Descriptors } \\
\text { externalities; biomass; biomass power technologies; energy market } \\
\text { b. Identifiers/Open-Ended Terms }\end{array}$}} \\
\hline & & & \\
\hline \multirow{2}{*}{\multicolumn{2}{|c|}{$\begin{array}{l}\text { 18. Availability Statement } \\
\text { National Technical Information Service } \\
\text { U.S. Department of Commerce } \\
\text { 5285 Port Royal Road } \\
\text { Springfield, VA } 22161\end{array}$}} & & $\begin{array}{l}\text { 19. No. of Pages } \\
68\end{array}$ \\
\hline & & & $\begin{array}{c}\text { 20. Price } \\
\text { A04 }\end{array}$ \\
\hline
\end{tabular}

Form No. 0069E (6-30-87) 